\title{
Order in the Bazaar: The Transformation of Non-state Law in Afghanistan's Premier Money Exchange Market
}

\author{
Nafay Choudhury
}

\begin{abstract}
Based on fourteen months of ethnographic research on the central money exchange bazaar in Kabul, Afghanistan-Sarai Shahzada - this article examines the micro-dynamics of legal change within a close-knit community in a fragile setting. For most of its history, the bazaar has been governed by informal legal norms. New state-building measures after 2001 led to increased efforts by the state to regulate the bazaar, causing money exchangers to initiate internal transformations to protect their autonomy. While scholarship generally argues that state coercion substitutes for private legal norms, this study shows the centrality of the state in consolidating the bazaar legal system. Exchangers have cast their non-state legal system in the image of the state by formalizing new operating rules that have introduced a management structure and dispute resolution forum. New state licenses have also helped to safeguard the boundaries of the bazaar. This article contributes to private governance and legal pluralism scholarship by revealing that a private community, even in a fragile state, may be capable of maintaining an autonomous non-state legal system not in spite of, but rather by depending on, the state.
\end{abstract}

\section{INTRODUCTION}

Why do some non-state legal systems persist over time? In Afghanistan, money exchangers have played a central role in supporting the economy for over two hundred years. Since the 1950s, exchangers have consolidated their activities in the country's central money bazaar-Sarai Shahzada - which is located on the Kabul River in the heart of the city. The four-story structure as it currently stands consists of approximately four hundred shops with a single entrance where people—-mostly men ${ }^{1}$ —of all walks of

Nafay Choudhury is the Jeremy Haworth Research Fellow, St Catharine's College, University of Cambridge, United Kingdom; Social Sciences and Humanities Research Council Postdoctoral Fellow, Faculty of Law, University of Toronto, Canada. Email: nc585@cam.ac.uk

The author received generous feedback and support from David Nelken, Florian Grisel, Farhana Rahman, Sapna Reheem Shaila, Nadia Lambek, Jiř́ Přibáň, Morag Goodwin, David Kennedy, Zulfiqar Ali Khan, Ahmad Milad Assakzai, Mohammad Amin Amin, Abdul Musawer Ishan, Amir Khan Saleh, Naveed Saif, Habib Faizi, Wahidullah Haidari, Angel Cabrera Silva, Michelle Wilde Anderson, Dan Farbman, and Jeffery Omari. The Afghan Institute for Strategic Studies provided an institutional home during fieldwork; the author thanks the director general, Davood Moradian, for his continued support. This research was made possible through funding from the Sociolegal Studies Association and the Dickson Poon School of Law, King's College London.

1. There is no rule prohibiting women from entering the bazaar, and in the different commercial markets across Kabul, it is common to see both men and women customers. However, during the course of my fieldwork, which involved multiple visits to the bazaar each week, I observed the presence of women in the bazaar only on a few occasions. 
life engage in financial transactions. Each person depends on the market for his or her own reason. Some need to transfer money abroad, while others wait to receive funds. Some see the bazaar as a place to safely store money, while a small few who possess a surplus of wealth seek to reap a profit by providing funds to exchangers as capital investment. Others simply need to exchange local Afghanis for one of the other currencies in circulation. Throughout most of its history, the affairs of money exchangers have always been regulated by the non-state legal norms of their close-knit community.

The reign of the Taliban government from 1996 to 2001 brought about a strong upturn in activities in the bazaar given the total absence of banking facilities during this period. The crowds of men that would flock to the bazaar-two stories high in those days-were so numerous that individuals would elbow one another as they hustled across the market floor. The events of September 11, 2001, significantly altered the trajectory of Afghanistan and the bazaar. The Taliban were ousted within a few months, and the international community - with the United States at the helm-commenced reconstruction efforts in the country. In the years that followed, development efforts got into full swing, and billions of dollars rolled into Afghanistan (Suhrke 2012; Bizhan 2018a, 2018b). By 2010, some seventeen banks were operating, several of which had agreements with foreign correspondent banks to make international bank transfers. Given the expansion of the banking sector, one may have expected that activities in the bazaar would shrink, with demand moving from the informal to the formal sector.

The reality was quite the contrary. Activity in the money bazaar sharply increased after 2001. Thanks to an economic upsurge fueled by foreign funds pouring into Afghanistan, the Afghan government as well as both local and international non-governmental organizations (NGOs) initiated countless development projects throughout the country. Money exchangers stepped up to provide the financial services needed to move hundreds of millions of dollars across various provinces. Furthermore, the heightened demands on the overall economy increased demand for imported goods from abroad (Marsden 2015, 2016, 2018), and exchangers provided the financial architecture that allowed for funds to move across regional and international boundaries. The intriguing success of the bazaar is not solely economic but also legal. After 2001, money exchangers continued to transact according to internal market norms while also introducing new practices into the bazaar. In the decade and a half following 2001, the bazaar underwent crucial internal transformations, which helped to consolidate its practices and its overall autonomy vis-à-vis a progressively expanding state.

This article studies the transformations in the bazaar over the past two decades that have allowed it to maintain an autonomous legal order that operates outside of the state legal system. Two transformations are explored in detail — the formation of an internal management structure in the bazaar and the formalization of a dispute resolution forum. These changes can be traced to the actions of money exchangers who sought to strengthen the authority of the bazaar, thereby maintaining its operational autonomy, while also transforming it through contact with the state and state actors. Furthermore, these transformations do not represent a wholesale rejection of earlier informal regulatory practices, which persist, albeit in a different form. The bazaar reveals how a closeknit community of actors has cast its non-state legal system in the image of the state by formalizing many of its affairs and has come to rely on the state to safeguard its boundaries. Formalization here refers to the process of regularization by instituting rules and 
structures, thereby providing a level of uniformity of activities. Nonetheless, while mimicking the state, these actors have been able to maintain long-standing informal regulatory practices, albeit in a new and altered form. The transformations within the bazaar show how state and non-state legal systems have become more closely entangled through their contact with one another, even while allowing the latter to maintain its autonomy from the former. Put in another way, greater interdependence has entailed greater independence-the more alike, the more apart.

This article makes three distinct contributions to the literature on law, private governance, and legal pluralism. First, the article offers a rare glimpse into the little-known world of Afghanistan's money exchangers, thereby adding a novel fragile state perspective to the discussion on legal order within private communities. Afghanistan is a particularly rich site to study non-state legal ordering in fragile settings. Fragile settings face unique governance challenges as the state legal system does not always have a monopoly over the rule of law and may be viewed as being incapable of impartially resolving disputes (Massoud 2013). In 2020, the Fragile States Index ranked Afghanistan as the ninth most fragile nation globally (out of 179), and the country has occupied a position near the top of this list for most of the last decade and a half since the index began. ${ }^{2}$ Decades of successive wars have crippled state functionalities, including justice institutions (Swenson 2017). Scholarship on private governance has predominately focused on communities within highly developed states with well-functioning legal systems (Ellickson 1991; Bernstein 1992; Feldman 2006). A handful of studies shine a spotlight on such communities in non-Western and fragile settings (McMillan and Woodruff 1999, 2000; Fafchamps 2004; Greif 2006; Paquin 2012; Grossman 2021), and this study adds much needed empirical variation within this limited subset of scholarship.

Second, and contrary to the prevailing literature, this article demonstrates how a non-state legal system may maintain its autonomy not by avoiding the state legal system but, rather, by depending on it. The money exchange bazaar conveys a story seldom told -namely, the reliance on the state, fragile as it may be, to consolidate the non-state legal system of a private community. Much of the current scholarship focuses on the functioning of private communities in highly developed countries and explains why and how such communities avoid state interference. Studies focusing on fragile settings tend to attribute the persistence of non-state laws to the absence of the state (Fafchamps 1996; McMillan and Woodruff 2000; Paquin 2012); accordingly, as the state expands, these non-state legal orders also disappear.

The money bazaar tells a different story. The legal system of the bazaar has been able to maintain its independence even during a period of rapid state expansion by transforming its operating structures. Exchangers have appropriated legal forms originating from the state-namely, its formalized and regularized operating structures—and have successfully institutionalized them within the bazaar. This transformation, while bringing the bazaar into closer alignment with the state, has also allowed for the former to maintain its autonomy from the latter. In the course of a few years, Kabul's money bazaar has transformed from an informal legal system operating without any centralized governance structure into a formalized and organized system that nonetheless continues to operate independently of state law. Furthermore, government licenses have helped

2. Fragile States Index, Global Data (2021), https://fragilestatesindex.org/data/. 
safeguard membership into the community of exchangers who work in the bazaar, further bolstering its overall cohesion. In sum, the bazaar's legal system operates not in spite of, but rather by depending on, the state.

Third, this article showcases the micro-dynamics of legal transformation when systems of order interact, revealing how formalization entails both change and continuity. The existing literature on private governance mostly describes how such communities function, placing less focus on how those functions transform over time, thereby allowing the community to maintain cohesion and normative authority under changing circumstances (Ellickson 1991; Bernstein 1992; Dixit 2004; Feldman 2006; Stringham 2015). Private communities are not frozen in time but, rather, are capable of evolving. In the bazaar, money exchangers have responded to changes in their environment by formalizing a written "statute" governing the affairs of exchangers and introducing a centralized management structure, including a dispute resolution "commission." These changes represent a break from previous practices, as no formal, regularized bureaucracy or set of rules existed prior; however, exchangers continue to draw extensively on prior practices. Most notably, the newly introduced dispute resolution commission in the bazaar relies extensively on prior informal legal norms. The continued reliance on these long-standing norms has helped legitimize the new changes introduced into bazaar's legal system.

This study is based on fourteen months of ethnographic fieldwork in Kabul, speaking to money exchangers, businessmen, central and commercial bankers, government officials, and justice actors as well as frequenting the central money bazaar (a site also frequented by insurgent groups). I carried out a total of 169 interviews, including with forty-six money exchangers, twenty-two businessmen, and fifteen government officials. ${ }^{3}$ I located my interlocutors through referrals from those in my personal network or people I had already interviewed, a method referred to as snowball sampling (Biernacki and Waldorf 1981; Atkinson and Flint 2001). I minimized selection bias by employing multiple snowballs simultaneously and interviewing individuals with competing interests, like state and non-state actors, and I conducted follow-up interviews to account for discrepancies. While I adopted an ethnographic method, my study of the bazaar is not a traditional ethnography since I did not seek to provide a representation of the social and cultural realities of the field but, rather, sought to answer a set of questions on normative ordering in the bazaar. My research is thus better considered as a contribution to socio-legal scholarship that adopts an ethnographic approach (Flood 2005; Coutin and Fortin 2015; Creutzfeldt, Mason, and McConnachie 2019). Order and transformation are a consequence of individuals acting and making decisions in an ever-changing world where macro-social structures exist but are susceptible to alterations. $^{4}$

3. Pseudonyms are used throughout this article for personal safety and privacy.

4. In this regard, my theoretical orientation aligns with theories on structuration. A concept introduced by Anthony Giddens (1986), structuration views social structures as being brought to life by actions. Margaret Archer (1996) advances this position by asserting that structures and actions transform one another. Archer's position thus validates interpretivism (see, for example, Geertz 1973) while also acknowledging how widespread social structures influence behavior (see, for example, Parsons 1937; Durkheim 1982). 
The second section reviews the extant literature more closely, thereby positioning the scholarly contribution of this study. The third section provides an overview of the central money exchange bazaar-Sarai Shahzada-and explains the informal legal system that has regulated the bazaar for much of its history. The fourth section details the emergence of a written and codified set of rules - the "Statute" — and a centralized management structure - the "Union of Exchangers" - within the bazaar over the past two decades. The fifth section looks at how the interactions of the state and bazaar have helped delineate the normative boundaries of the bazaar, thereby strengthening its authority within those bounds. The sixth section looks at the functioning of the newly formed Conflict Commission, the bazaar's dispute resolution forum. The seventh section briefly considers the availability of state courts for resolving disputes. The final section concludes the article with a discussion on why formalization succeeded in maintaining the autonomy of the non-state legal system of the bazaar.

\section{THE TRANSFORMATION OF NON-STATE LEGAL SYSTEMS}

It now seems trite knowledge that legal pluralism is widely pervasive in Afghanistan, with state law, Islamic law, and customary law all playing a role in the administration of justice (Ahmed 2007; Barfield 2008; Wardak 2011; Wardak and Braithwaite 2013; Choudhury 2014, 2017; Khan 2015; Rahbari 2018). Afghan state law itself is comprised of a patchwork of official enacted laws, rules derived from Islamic law that are often contained in unofficial manuals of Islamic jurisprudence, and customary laws that supply state rules with normative meanings. More interesting and less understood are the ways in which such differing legal systems transform over time through their interactions with each other (Merry 1988; von Benda-Beckmann and von Benda-Beckmann 2006). When legal systems come into contact, frictions may arise due to competition for authority and conflicting propositions on how to deal with problems (Tamanaha 2008; Swenson 2018).

Two bodies of scholarship highlight the interaction of state and non-state legal systems within the same social space. The first body can be broadly grouped as the private governance literature (Stringham 2015; Richman 2017). These works, strongly influenced by the fields of new institutional economics (North 1990) as well as law and economics (Coase 1937; Ellickson 1991) became prominent in the 1990s when diverse studies emerged on the ways in which close-knit communities governed their activities based on their own rules rather than relying on public coercion. These studies show how private communities may "opt out" of the state legal system (Bernstein 1992), despite the latter being fully functional within society. Professional associations, such as the National Food and Grain Association (Bernstein 1996) and the Liverpool Cotton Association (Bernstein 2001), represent private communities that host their own system of rules and coercion separate from the state legal apparatus. A common explanation proffered is the existence of efficiency gains achieved by private coercion over state courts (Richman 2004, 2332)_disputes are resolved quicker and more cheaply, rules and remedies are tailored to meet industry needs, and reliance on the community avoids difficult questions on facts that a court cannot easily ascertain (for example, Bernstein noted how, in the cotton industry, questions on varying grades of cotton are difficult to 
measure by industry experts, let alone by court officials). A tendency within this scholarship has been to focus on private communities in highly developed states, where the choice to avoid the state legal system seems anomalous. Conversely, in fragile settings, the tendency has been to treat private coercion within close-knit communities as playing a residual role in the absence of adequate state legal remedies (Fafchamps 1996; McMillan and Woodruff 2000; Paquin 2012). The money bazaar provides an alternative narrative-namely, a non-state legal system whose autonomy and operations depend on its interactions with the state.

A second body of scholarship that this study engages with is the literature on legal pluralism, which concerns the "fragmented nature of authority" faced by many societies "in relation to the administration of justice" (McConnachie 2014, 12). In many settings, state law may not have a monopoly over legal authority and may not even be the most influential system of legal ordering (Griffiths 1986; Merry 1988; Woodman 1998; Tamanaha 2008); rather, various non-state legal systems may command significant regulatory authority (Michaels 2005; Hertogh 2008, 2009). Furthermore, legal pluralism scholarship goes beyond simply advancing the existence of multiple legal orders in a single social space by looking at the "dynamics of change and transformation" from their contact with one another (Merry 1988, 879). As Boaventura de Sousa Santos (1995, 464) contends, "more important than the identification of the different legal orders is tracing the complex and changing relationship amongst them." Afghanistan's central money bazaar helps reveal what the mixing of legal systems looks like in practice. The entanglements that draw legal systems into closer contact with one another may also sharpen the distinction between them. Moreover, while legal systems may borrow elements from one another, these transfers take on a new form when they combine with the already existing legal structures of the recipient system (Englund 2006; Kurkchiyan 2009; Gillespie and Nicholson 2012; Chua 2015).

One of the insights from legal pluralism is that the contact of different legal systems facilitates cross-contamination of norms and legal borrowing. Legal systems should be treated as "semi-autonomous social fields," to use Sally Falk Moore's (1973, 720) classical concept, that "can generate rules and customs and symbols internally, but [that are] also vulnerable to rules and decisions and other forces emanating from the larger world by which it is surrounded." Legal pluralism often entails ongoing interactions and legal borrowing between systems, which are not immediately captured when taking a descriptive snapshot of a particular social setting. For this reason, de Sousa Santos (1995) recommends that legal systems should not be studied in isolation; instead, emphasis should be placed on "interlaw" or "interlegality" - that is, on how these systems function when they interact with one another.

Certain non-state legal systems may be particularly well suited for receiving foreign legal constructs. Reception of these foreign elements may be viewed as desirable if it would strengthen the functioning of the recipient system. De Sousa Santos's (1977, 54) study of a Brazilian favela reveals the borrowing of legal concepts from the state, which helped to "(1) guarantee the normative survival of [the non-state legal system] in a situation of legal pluralism in which the official law has the power to define normative problems, but cannot solve them; (2) respond to social conditions and institutional resources of the community that differ from those in the larger society that gave rise to the official law." Actors that are part of a private community may strategically deploy 
legal constructs originating from the state to achieve their own ends, such as consolidating the authority of their legal system. While these transferred legal constructs bear resemblances to the state legal system from which they originated, they are also transformed as they adapt to the mores of the recipient non-state legal system.

Whether a legal system is able to persist during periods of transformation often depends on whether it can maintain its boundaries and, moreover, its authority within those boundaries. Karen Clay's (1997) study of a coalition of traders in California (then part of Mexico) in the 1830s argued that America's annexation of the area allowed merchants to rely on the state legal system; during this same period, the start of the gold rush in the area led to crews deserting their ship in search of better opportunities. Consequently, the reduced size and strength of the transportation-cum-information network amongst traders weakened the effectiveness of the reputational sanctions within the coalition, eventually causing its collapse. A study by Christopher Woodruff (1998) found that Mexican shoe associations, at one time controlling two-thirds of the country's shoe production, collapsed following trade liberalization, as retailers could choose to buy not only from local manufacturers but also from foreign sources, thereby extinguishing the ability of these associations to coerce the behavior of retailers through sanctions. Furthermore, when newcomers with their own practices or norms infiltrate an otherwise self-regulating community, the latter may lose its ability to maintain order. In his research on a fishing community in Marseille, France, Florian Grisel (2021) found that the inability of the incumbent community to assimilate its newcomers caused the community to collapse since the social norms followed by the former failed to keep up with new social practices introduced by the latter.

Afghanistan's money exchange bazaar provides a vivid case study of how the interaction between money exchangers and state actors has helped maintain — and arguably strengthen - the autonomy of the bazaar as a close-knit community following its own system of rules. Studies on private governance in fragile settings tend to treat state and non-state legal systems as substitutes (McMillan and Woodruff 2000); consequently, as the state legal system gets stronger, it crowds out the legal systems of private communities. One notable exception is Shelby Grossman's (2021) quantitative study of several hundred market associations in Lagos, Nigeria, which posits that a predatory government incentivizes private market communities to strengthen their non-state legal systems, thereby preventing the government from meddling in their affairs. In one sense, Grossman's findings are consistent with the dynamics of order in my study since an encroaching state initiated internal transformations within Kabul's money bazaar. However, Grossman's study points to an antagonistic relationship between the state and private markets, whereas, in the bazaar, the relationship is simultaneously antagonistic and collaborative.

Since 2001, money exchangers have faced pressures from an encroaching state that risked undermining the bazaar as well as from recalcitrant exchangers who risked undermining public confidence in the community. The bazaar's contact with the state initiated a set of transformations that helped consolidate its authority through the formalization of its administrative structures. Consolidating its authority was a means of addressing these threats. However, to say that the bazaar has maintained its independence by opting out of the state, similar to various professional associations in other settings (Bernstein 2001; Richman 2006) obfuscates the dynamics of change. 
The ethnographic approach of this study helps track the seemingly contradictory behavior of money exchangers, who at once opted out of the state legal system even while relying on the state to support the functioning of the legal system of the bazaar.

Law possesses the ability to create images of society that "in turn impact upon society at a discursive level and influence the way we think about and experience law" (Banakar 2011, 13). While law and society research focuses on the constitutive role of enacted law in producing categories and concepts through which the world is organized (Garth and Sarat 1998), the way this process plays out may be rather circuitous. In Afghanistan, enacted state laws provide a template based on which exchangers have developed and formalized the legal system of the bazaar. The formalization of non-state law has transformed the behavior of exchangers as their affairs now rely on a combination of formal and informal non-state legal norms. Thus, like state law, non-state law also possesses the capacity to recast society in its image by structuring the social world. Exchangers have come to conduct their affairs in line with the new structures of their non-state legal system, and, by ascribing to its rules, exchangers in turn legitimize its authority.

In the discussion that follows, my goal is not to simply describe, but also to explain, the transformations in the legal system of the bazaar. Exchangers have been able to maintain the autonomy of the legal system of the bazaar by mimicking legal forms originating in the state; moreover, the process of transformation has entailed new operations within the bazaar while also continuing to draw from prior regulatory practice.

\section{A BAZAAR COMMUNITY}

Kabul's central money bazaar-Sarai Shahzada-is located on the path of the Kabul River, just past Pul-e Bagh-e Omomi, an iconic bridge at the heart of the old city. The four-floor building is otherwise indistinguishable from the many others now competing in stature but for the thirteen billboards of various banks conspicuously running across its rooftop. Its single entry gate, manned at all times by two police officers, leads into the economic heart of the country, the central money bazaar. ${ }^{5}$ While innumerous money exchangers-locally referred to as sarrafs — can be found throughout Afghanistan, the bazaar houses the most prominent ones in the country. The roughly four hundred shops spanning the four floors of the bazaar range in size from fifty to one hundred square feet and resemble small board rooms, seats lining their inside walls and a large coffee table sometimes occupying the center space. Situated at the backend of most offices is an elongated counter manned by one or two employees. A customer approaches the employee the way one would approach a teller at a bank, the two often separated by a glass barrier. The open-air configuration of the bazaar permits ample sunlight and fresh air, though rendering it wet and frigid through the winter months. Within this simple yet vibrant setting, hundreds of millions of dollars circulate each day, making it the financial hub of the country.

5. Kabul also has a number of small exchange bazaars, ranging in size from five to fifty shops. These other markets predominately engage in currency exchanging, whereas exchangers in Sarai Shahzada also engage in hawala transfers and credit financing. 
By no coincidence, the central money bazaar sits adjacent to the famous street of Mandawi, shorthand for the market of Kabul's merchants and traders, roughly two square kilometers in size and hosting thousands of private businesses. As a landlocked country with a limited industrial and production sector, Afghanistan relies on neighboring countries for its goods. Traders and merchants ensure that every possible good is imported from abroad, from kitchen utensils, to luxury furniture, to electronics. The affairs of Afghan merchants and money exchangers are deeply entangled as the former rely on the latter for transferring funds to and from suppliers and customers located abroad or across the country. Within the money bazaar, exchangers perform a variety of transactions, including currency exchanges, money transfers, storing money for safekeeping and trade financing (Choudhury 2021). The sizeable volume of trade with nearby countries has caused many foreign currencies to be in circulation in the Afghan market, and Afghan merchants rely on the foreign currencies provided by exchangers to acquire their goods from abroad. People in Afghanistan also regularly cross into neighboring countries, whether for work, medical services, or education, thus requiring foreign funds.

Exchangers also offer loans; when a merchant has developed a relationship of trust with an exchanger, he may be able to acquire credit from the exchanger, thereby allowing him to expand the scale of his business. Money transfers are executed using a hawala system (Choudhury 2021; Rahimi 2021). A hawala money transfer involves the cooperation of business partners in two distant locations. For example, an exchanger in the bazaar may have a partner in Tajikistan. This partner will have some clients seeking to send funds to Kabul and other clients waiting to receive funds from Kabul. The two partners offset inflows and outflows of funds, such that, at the end of a given period, only a small amount of funds needs to be transferred between them. When the two need to offset funds, they may do so using bank transfers, through a trusted third party, or even by physically transporting the funds. ${ }^{6}$ As one exchanger explained to me with a smile, "at the end of the day, there might be risks, but we'll find a way." "The combination of exchangers in the money bazaar forms an extensive hawala network covering the entire country and extending across many parts of the globe.

The precise economic scale of the bazaar remains unclear since no official figures exist on the volume of funds in circulation. Nonetheless, some indications can be adduced from related figures on the economy. Several times each week, the Afghan central bank sells American dollars to exchangers through an auctioning process to soak up excess local Afghanis from the economy. The total amount auctioned in 2017 was approximately $\$ 2.1$ billion. ${ }^{8}$ Exchangers subsequently use these funds to perform transactions across the economy requiring American currency. The significance of this scale of activity becomes evident when noting that the country's annual gross domestic product in 2017 was in the order of $\$ 20$ billion and that the total holdings in all the

6. Hawala networks extend into dangerous areas of the country. Exchangers often shoulder the risk of transporting funds into these areas through trusted third parties. The risks associated with operating in these areas put a premium on their services.

7. Musadeq (money exchanger), interview by the author in Kabul, Afghanistan, February 2020.

8. Da Afghanistan Bank (DAB), Annual Report 1396 (2017). The DAB follows the solar hijri calendar, and, thus, 1396 covers the period 21 March 2017 - 20 March 2018. Based on my calculations for the year 2018. 
commercials banks was $\$ 3.59$ billion in the same year. Furthermore, the comingling of licit funds with illicit funds from Afghanistan's thriving opium economy-Afghanistan is the largest exporter of opium globally, providing the country with approximately $\$ 1.4$ billion in 2017-further increases the volume of funds in circulation within the bazaar. ${ }^{9}$

For most of its history, the bazaar has had no formalized process of dispute resolution since exchangers resolved their problems informally. ${ }^{10}$ The legal system of the bazaar consisted of informal mediations involving the disputing parties and fellow exchangers. If two exchangers had a problem, they would first try to resolve the matter between themselves. If the issue persisted, respected friends and elders in the bazaar would be called upon to intervene. Within traditional Afghan society, when problems arise between parties, the community often convenes a shura or jirga (a gathering of respected elders of the community), ${ }^{11}$ whose members mediate a solution according to community norms (Rubin 2002; Barfield 2008). Through the shura/jirga structure, elders can diffuse conflicts, thereby reconciling the parties and maintaining the overall cohesion of the community. This traditional practice was pervasive in the bazaar as respected exchangers would be called upon to mediate a solution based on community norms.

The close-knit nature of the community facilitated two forms of community coercion: reputational damage and social ostracism. Private communities in various settings employ these sanctions to control the behavior of members and to punish recalcitrance (Ellickson 1991; Bernstein 2001; Richman 2017). Close-knit communities facilitate the "network effect," which represents the potential for information to spread quickly to community members (Katz and Shapiro 1994). Disputant parties face strong social pressure to adhere to collective decisions as negative gossip could damage a party's reputation and, in the extreme, may lead to the exclusion of that party from the community. Exchangers in the bazaar depend on one another to carry out many of their transactions, and, thus, community cohesion has been essential for their individual success. None of the substantive rules or procedures were written or codified in any form since exchangers adhered to prevailing community practices acquired through time and experience in the bazaar. The respect wielded by elders helped mend rifts between parties, and the threat of losing face before one's peers coerced exchangers into adhering to their decisions. In this way, exchangers were able to regulate their affairs without relying on the state legal system. Only after 2001 did the informal legal system of the bazaar begin to transform and take a new shape.

9. In this article, I do not focus on the role that exchangers and the money bazaar plays as a cover for laundering funds from corrupt government officials and the illicit opium trade. While I recognize that some exchangers may engage in these activities, my study seeks to understand the running of the non-state legal system of the bazaar. For the role of exchangers in facilitating the opium trade, see, for example, Thompson 2011.

10. Wahab (money exchanger), interview by the author in Dubai, United Arab Emirates, October 2017. This description of informally resolving disputes was repeated by some ten exchangers. Similarly, in her study of Afghan hawala networks, Edwina Thompson $(2011,173)$ found that parties informally resolved their disputes, as mentioned by one exchanger that she interviewed: "If someone does something wrong to me, a few men will gather in my shop. ... We settle the problem in maybe a few hours, or sometimes it takes a week."

11. This gathering is normally attended exclusively by male community members. 


\section{EMERGENCE OF THE UNION OF EXCHANGERS}

\section{The Need for Centralized Authority}

The centralized management structure within the bazaar is a new phenomenon. When the bazaar first took up its current location in Sarai Shahzada in the 1950s, it operated without an internal hierarchy. ${ }^{12}$ During those formative years and as the market grew, one of the exchangers-an individual well respected by the shops- would be informally selected to serve as their "head," although the position held no formal authority and lacked a clear mandate. Reflecting on the bazaar in the 1980s and 1990s, one exchanger remarked: "They [that is, the head exchanger] like to make speeches here and there, but they didn't really do anything." 13 The core preoccupation of exchangers back then - as it is now-was to facilitate the transactions of their customers, which provided exchangers with their income. The head exchanger would help resolve disputes in the bazaar or respond to requests from the government with the interests of exchangers in mind. However, he was otherwise uninvolved in the dayto-day transactions of exchangers. No evidence exists of any management structure within the bazaar prior to 2001.

Starting in late 2001 following the fall of the Taliban government, money started entering the country at a rate previously unfathomable (Bizhan 2018b). Projects by international actors, NGOs, and the Afghan government mushroomed nationwide, requiring a system that could facilitate the movement of funds (Maimbo 2003; Thompson 2011). Consequently, exchangers became clearinghouses for funds being transferred to all parts of Afghanistan. The size of the bazaar quickly swelled, as new exchangers opened shops to partake in this surge in activities. Around 2001, exchangers held their first elections to choose a president who would represent their interests as needed. ${ }^{14}$ This elected head was responsible for representing the collective interests of exchangers, particularly in relation to the burgeoning government. Beyond this general responsibility, the position lacked a clear mandate. Disputes in the bazaar continued to be resolved by respected exchangers. Edwina Thompson's $(2011,173)$ interview with an exchanger in the bazaar in 2005 reveals the limited authority of the hierarchal management structure of the bazaar: "We have heard of this group of men who call themselves the 'Money Exchange Dealers' Association', but laugh at them for they have no power. They like to give themselves titles so that the international community will go and speak with them and consider them important. The reality is different."

With the steady growth of the country's economy, the number of exchangers in the bazaar quickly increased; however, these new economic opportunities also entailed new

12. The current location of the bazaar dates back to 1957, consisting of three or four Afghan Jews. Afghan Hindus and Sikhs entered the bazaar by 1960 and soon overtook the market through their fierce competition. When the Communist government took over Afghanistan in 1978, the Afghan Hindus and Sikhs withdrew from the market, at which time it was taken over by Afghan Muslim exchangers. For information on the bazaar's functioning up until the 1970s, see Fry 1974.

13. Wahab (money exchanger), interview by the author in Dubai, United Arab Emirates, October 2017.

14. Amongst the exchangers I talked to, there was disagreement over whether these elections commenced in 2001 or 2002. However, all agreed that it was sometime soon after the fall of the Taliban. 
market woes. The bazaar came under pressure from two directions: the government and the exchangers themselves. Government institutions slowly strengthened and sought to bring activities across society under their control, including the affairs of money exchangers (Maimbo 2003). One potential means of accomplishing this goal was through registration. Registration would allow the government to identify exchangers, with the goal of eventually monitoring their transactions. The government faced pressures from the international community to monitor illicit transactions associated with the opium trade and the financing of terrorism, some of which was channeled through the bazaar (though the precise volume was unclear) (Thompson 2011). Registration and subsequent monitoring would be one method of identifying the flow of illicit funds. Furthermore, the near collapse of Kabul Bank in 2010 due to fraudulent activities by its banking officials put further stresses on the entire financial sector (Higgins 2010), with the government and the international community realizing that the Afghan central bank-Da Afghanistan Bank (DAB) — needed to monitor the country's financial institutions more strenuously, including the activities of money exchangers given their central role in financial transactions and mediation.

Exchangers also faced mounting pressures internally from the nefarious activities of certain exchangers within their ranks, which risked damaging the image of the entire bazaar. The functioning of the bazaar depends on people across society having trust in money exchangers as a collective. The strong reputation of many, if not most, exchangers bolsters the overall reputation of the bazaar and the trust that people have in it. This trust may be considered to be a form of collective social capital that increases through the reputation of the exchangers and the expansion of the geographic networks created by their cooperative efforts (Coleman 1988; Putnam 1993). New exchangers in the bazaar automatically gain access to this social capital, which raises the problem of freeriding - that is, benefiting from communal resources without making any contribution. A deceitful exchanger can potentially reap significant gains by abusing the trust afforded to him by virtue of his association with the bazaar. Unfortunately, such problems have arisen in the past. Certain exchangers have run off with funds, leaving their investors without any recourse. Others were caught dealing with proceeds from the opium trade, even catching the attention of the Central Intelligence Agency (Rosenberg 2011).

The relationship between the bazaar and the proceeds of illicit funds is complex. While every exchanger who I interviewed recognized that some exchangers dealt with such funds, none had any way to quantify the volume of such activities. Previous studies have shown exchangers in different parts of Afghanistan to be complicit in the transfer of drug money (Thompson 2011). When people associate exchangers with illegal activities, it harms the overall reputation of the bazaar, leading to a loss in customer confidence. Exchangers dealing with funds from illegal sources-whether from the opium trade or corrupt government officials - risk having their money seized by the government. To escape government detection, some may choose to abscond without notice. Consequently, their customers risk losing their funds or alternately having them detained by the government pending a lengthy investigation. Particularly unlucky customers may find themselves the target of government questioning and suspicion. Such activities weaken overall public confidence in the bazaar, adversely affecting all exchangers, especially those who avoid dealing with funds from illicit sources and instead focus on mundane financial transactions-even if unregulated or 
under-regulated-from currency changing, to hawala money transfers, to credit financing, to providing savings accounts. Exchangers have a valid reason to be concerned about the behavior of fellow exchangers-if clients cease to trust exchangers or if exchangers lose trust amongst one another, their entire system would risk collapse.

The Union of Exchangers (the Etihadiya) emerged in 2010 as a response to these mounting pressures against exchangers. Several senior and long-standing exchangers from different ethnic backgrounds came together with the intent of addressing these problems by collectively organizing. These exchangers had been operating since the fall of the Taliban (and many had been in operation even prior to this time) and thus were witness to the changes taking place within the bazaar. For them, establishing a formal management structure would provide a means of both protecting exchangers against government intrusions as well as regulating the behavior of exchangers. Such a structure would also provide incumbent exchangers with greater control over new market entrants and, thus, the overall reputation of the bazaar. One of the founding members of the Union explained its underlying rationale: "Establishing the Union was important for two reasons: first, because we needed to centralize authority to represent 400 offices and solve their problems and those of their customers. Second, with the Union, money exchangers would be less vulnerable to unfavorable demands of the Central Bank." ${ }^{15}$

Up until the emergence of the Union of Exchangers, the actions of exchangers were uncoordinated. No organizational structure existed that could help mobilize collective action. Prior to 2001, a lack of centralized authority was not particularly consequential for exchangers given the lack of organization of the state as well as the comparatively limited volume of funds passing through the bazaar. However, after 2001, the sweeping changes in Afghan society generally, and within the bazaar specifically, placed the activities within the bazaar at the center of state-building efforts. These changes risked destabilizing the operation of the bazaar. An informally elected president without a clear mandate had insufficient ability to represent exchangers before the government as the scope of his roles and responsibilities remained unclear. Furthermore, exchangers had limited ability to control the actions of other exchangers, even if dubious actions of the latter could affect the overall image of the bazaar. Exchangers viewed the creation of a management structure as a means of countering these different pressures. Exchangers in the bazaar already constituted a close-knit community with commonly understood norms and practices. A centralized body could help coordinate different functions amongst exchangers, whether resolving disputes or speaking to government officials with a unified voice. Such a body would ensure that decision-making authority on matters relating to their affairs would remain within the bazaar.

A few exchangers voiced somewhat expected reservations about a proposed management structure-namely, the fear that their business activities may be affected by the existence of a union. ${ }^{16}$ These exchangers were concerned that changes placing them within a larger bureaucratic structure may interfere with their abilities to transact with clients. Others were concerned that a union would be susceptible to ethnic politics and polarization, with dominant groups seizing power and promoting their own interests,

15. Abdul Sami (money exchanger), interview by the author in Kabul, Afghanistan, February 2018.

16. Khalil (executive of the exchanger Union), interview by the author in Kabul, Afghanistan, March 2018. 
quite possibly to the detriment of other exchangers. A management structure would change the power dynamics within the bazaar by providing some with greater decision-making authority on certain matters. Avoiding potential power struggles required specifying those matters that fell under the authority of the management structure and ensuring that the latter encapsulated the collective interests of exchangers. In this way, a central structure could foster collaboration and strengthen trust between exchangers rather than trigger divisive politics.

While concerns existed over centralization, exchangers shared a common concern about the mounting pressures on the bazaar and, thus, the need to collectively strategize. Essential in establishing the Union of Exchangers was its endorsement by long-standing exchangers from different ethnic groups-Pashtun, Tajik, Hazara, and Uzbek. ${ }^{17}$ These exchangers often held influence amongst members of their own ethnic group in the bazaar, and, thus, their endorsement helped promote the idea of a centralized body and encouraged its widespread acceptance. Furthermore, given the relatively small size of the bazaar, all exchangers possessed the ability to partake in the discussions on the merits and demerits of establishing a union.

Through an eventual vote involving all the exchangers in the bazaar, the governing Statute-the Asasnamah-was drafted in 2010 and breathed life into the centralized Union of Exchangers. ${ }^{18}$ The final approval of the Statute transformed the bazaar from an informally organized market to one that was formally constituted with a centralized body - namely, the Union of Exchanger — which was responsible for overseeing the activities of the bazaar while remaining minimally intrusive in the day-to-day activities of exchangers. The Union serves as the official representative body for all exchangers in the bazaar in discussions with the government on matters affecting the functioning of exchangers. Furthermore, the Union also unofficially represents exchangers in other bazaars throughout the country, as their interests are encapsulated by the Union even if they are not formally members (as formal membership in the Union is limited to those located in the central money bazaar). ${ }^{19}$

\section{Drafting the Statute of the Bazaar}

Establishing a centralized, administrative body involved drafting a set of rules outlining its roles, responsibilities, and operating structure. A handful of stalwart exchangers from different ethnic backgrounds led these efforts as they not only had foresight from being in the market for many years but also the trust and respect of fellow exchangers. Exchangers in the bazaar participated in a communal session that set into motion the drafting of rules:

17. In mid-2018 during my fieldwork, of the roughly four hundred shops in the bazaar, approximately half had Pashtun owners, 150 had Tajik owners, forty had Hazara owners, and ten had Uzbek owners. These figures change regularly.

18. Asasnamah (Statute of the Union of Tellers and Money Exchangers for Sarai Shahzada in Kabul), 2017 (Statute). There is disagreement on whether its first draft was adopted in 2010 or 2011. The official Statute is bilingual, written in both Dari and Pashto languages.

19. Other exchangers in the country informally look to the Union to represent their interests. However, only exchangers with physical shops in the central money exchanger bazaar vote in the elections of the Union and serve on its committees. 
The four hundred exchangers participated in a big session and selected only ten people to write the Statute for the Union. All articles of the Statute were studied carefully in order to represent the best interests of exchangers, and this Statute was confirmed by the majority of exchangers. Exchangers were not against establishing a union because the decision was made based on the necessities of Sarai Shahzada. Economic issues are included in the Statute, but there are not any political issues included in the Statute. All exchangers accepted the Statute, as it was made by the consent of every exchanger here. ${ }^{20}$

During this drafting process, one of the principal concerns amongst exchangers was the precise mandate of the Union as skeptics and those reluctant to vest authority in a centralized body sought to ensure that its functions were clearly defined: "Disagreements over the responsibility of the president of the Union, conditions of the presidency, authorities of commissions, and rights and responsibilities of members were among the key challenges during drafting." 21 While exchangers in the bazaar drove the drafting process, it also involved the input of professors and lawyers who helped with the wording of the text. ${ }^{22}$ To ensure widespread support and avoid potential divisiveness, particular attention was placed on ensuring a completely apolitical tone in the rules that would not favor any subgroup or person. Exchangers already understood the importance of working beyond ethnic boundaries for the success of their trade. In day-to-day life, exchangers harboring animosity toward other ethnic groups still expressed their open willingness to work with members of those groups if a transaction required it (Thompson 2011). Such an approach facilitated the strongest and most widespread economic network, which was beneficial for all exchangers. All exchangers understood their common interests, and they all sought protections against government intrusion. Likewise, they sought to protect themselves from recalcitrant exchangers as well as the general insecurities associated with dealing with so much cash. ${ }^{23}$

Even after the approval of the Statute in 2010 by exchangers, members of the Union continued to seek the input of government officials to refine its wording. The Statute was shared with the government specifically to receive input on the coherence of its wording as well as its consistency with the enacted provisions of law, particularly those of the central bank: "We drafted the statute and shared it with the Ministry of Justice of Afghanistan. We discussed the law with the lawyers of the Ministry to confirm the consistency of the draft law with other laws of Afghanistan, and they approved and passed the drafted law." 24 As another exchanger explained, "we established the rules in order to work in a legal framework and meet the requirements of the Central Bank's Audit Department." 25

The Ministry of Justice provided its legal expertise to confirm that the letter of the law coincided with the collective interests of the exchangers and that all the provisions

20. Karmal (executive of the Union of Exchanger), interview by the author in Kabul, Afghanistan, December 2017.

21. Haji Khan (money exchanger), interview by the author in Kabul, Afghanistan, November 2017.

22. Mashal (money exchanger), interview by the author in Kabul, Afghanistan, February 2018.

23. Daanish (money exchanger), interview by the author in Kabul, Afghanistan, December 2017.

24. Khodadad (executive of the Union of Exchangers), interview by the author in Kabul, Afghanistan, December 2018.

25. Haji Khan (money exchanger), interview by the author in Kabul, Afghanistan, November 2017. 
of the Statute were consistent with government laws and regulations. These efforts by the ministry were not viewed as unduly intrusive but, rather, materialized at the behest of the Union since the latter sought to strengthen the authority of its constituting Statute by ensuring that it was cast in a legal form and that it had the approval of officials at the ministry. While the Union executive remarked that the Ministry of Justice "passed the draft law," the ministry did not present the draft Statute before the Afghan Parliament (the body responsible for enacting legislation); however, in approving the wording of the Statute, the ministry provided state-sanctioned legitimacy to the Statute. In 2017, a booklet containing the finalized version of the Statute was published by the Union in both Dari and Pashto languages, the two most widely spoken languages across the country and within the bazaar. Its introduction included the endorsements of not only the Union but also the Ministry of Justice and the Afghan president, Ashraf Ghani. The Statute is the end result of nearly a decade of efforts to create a centralized management structure governed by a formalized set of rules.

\section{From Legal Informality to Formality in the Bazaar}

The published Statute clearly resembles enacted government laws or regulations. Written with clarity and organization, its thirty-five articles spread over five chapters provide details on the objectives of the Union, ${ }^{26}$ the rights and obligations of members, ${ }^{27}$ and the organizational structure of the Union. ${ }^{28}$ The Statute emphasizes the moral responsibilities of the Union, which must "support national interests," "defend the national values of Afghanistan," and "defend human rights in accordance with Afghan morals and Islamic principles." ${ }^{29}$ Extensive details on the elections process and the responsibilities of the president of the Union address the concern raised by many exchangers during the drafting phase that the Union's leadership roles needed to be clearly defined. ${ }^{30}$ The Statute also details the functions of the five standing committees-referred to as "commissions"-where some of the more low-key, but still vital, activities of the Union occur (as explained later in this article, the Conflict Commission is the one exception as it is anything but low key). ${ }^{31}$ Throughout the Statute, exchangers are called upon to uphold camaraderie, unity, and equality. ${ }^{32}$ Members have an obligation to "legally object to social injustice, corruption, and cruelties" and to prefer "national interests" over sectarianism. The Statute also emphasizes the equal rights of all members regardless of their background. The apolitical tone of the Statute underscores the objective of providing a structure that is capable of bringing together exchangers of all backgrounds (ethnic, political, religious, and otherwise) and protecting their collective interests.

26. Statute, Art. 7.

27. Statute, chap. 3.

28. Statute, chap. 4.

29. Statute, Art. 7(15).

30. Statute, Art. 22.

31. Statute, Arts. 23-33. The five commissions are: communication, finance, culture, election, and conflict resolution.

32. Statute, Arts. 9, 14(1). 
Nonetheless, despite its outward legal form, blessings from the Ministry of Justice and the president, and commanding authority amongst exchangers, the Statute does not represent a piece of enacted legislation or regulation that has been promulgated by the government or one of its organs. Rather, it is the outcome of the bazaar and the exchangers operating within it. It traces its authority to the support that it receives from the community of exchangers in the bazaar. Its very existence is the result of exchangers working to ensure that they maintain control over their affairs. The Statute helps protect exchangers from undue interference from the state. Even as a non-state law, the Statute is much more authoritative than many enacted state laws, the latter of which often gain limited traction in practice (Choudhury 2017). The Statute plays a recognizable role by bringing the Union and its committees into being and shaping a number of the activities of exchangers.

Through the enactment of the Statute, the legal system of the bazaar has transformed from an informal system to one hosting a centralized body whose bureaucratic structure operates according to a formalized set of rules. This transformation has occurred because of changing market conditions and changing relations with the state. The burgeoning state's presence presented both challenges and opportunities for exchangers. On the one hand, the state's greater regulation of exchangers threatened their ability to carry out their transactions freely. On the other hand, the rapid efforts at formalizing aspects of the state's legal system provided a window of opportunity for the bazaar to develop its own legal structures. The Statute is simultaneously a response to the encroaching presence of the state and a reflection of the legal formality associated with the state. International state-building efforts in Afghanistan have led to an expansion of the legal system through the enactment of a myriad of laws and regulations, including those that apply to the banking system and financial institutions. ${ }^{33}$ A prominent feature of the Afghan legal system has become the prevalence of enacted, written laws. For its part, the bazaar legal system has operated without formal rules throughout much of its history. Its recent transformation toward a formalized set of rules mimics the structure of the codified and formalized state legal system. Law's malleability in the bazaar-its ability to transform according to circumstances- has allowed exchangers to mimic state efforts to assert its authority by enacting its own set of private rules. The Statute represents the reception of a particular aspect of the state legal system into the bazaar-namely, the formalization of rules into a written and codified form.

What has occurred in the bazaar is not the "formalization of law" in the sense of non-state laws being integrated into the enacted laws of the state but, rather, the transformation of the bazaar's legal system through the codification of its rules. In certain settings, the state legal system may incorporate non-state legal practices into laws or legal structures of the former, sometimes referred to as "formalizing the informal" (De Soto 1989). Eric Feldman's (2006) study of the tuna court in Tokyo represents one such community whose norms were absorbed into the state legal system as the tuna court is an organ of the state. Similarly, colonial regimes that transplanted Indigenous laws into their legal systems had the effect of transforming non-state laws into state laws (Gluckman 1973). The changes occurring in the bazaar are distinct. In mimicking a particular legal form-namely, written and codified rules-associated with the state

33. For a list of some of these laws, see the DAB website, https://dab.gov.af. 
legal system, exchangers have been able to consolidate and bolster the autonomy of the bazaar's legal system. The exercise of developing, enacting, and implementing the Statute has transformed the informal legal system of the bazaar into a system consisting of formalized rules that are widely supported by exchangers and approved by the Ministry of Justice. The Statute has breathed life into the Union, which has centralized the activities of the exchangers that had previously been dispersed and imprecise. Thus, just as the state legal system has been developing over the past number of years, so too has the bazaar's legal system, and, in doing so, the latter has been able to maintain its autonomy.

The Statute helps delineate the boundary between the bazaar and the state. By better defining its own internal operating structure, the Union has been able to assert authority over the activities taking place in the bazaar while emphasizing the relationship between the Union and the government. The Statute declares the Union to be independent of the central bank and other organs of the state. ${ }^{34}$ Furthermore, the Statute empowers the Union to work with the government to implement policies beneficial to exchangers. ${ }^{35}$ Any problems arising within the bazaar are to be dealt with by the Union and should only exceptionally, and at its own behest, be referred to the state. ${ }^{36}$ The Union is also responsible for supporting exchangers who face legal claims raised by the state. ${ }^{37}$ One of the stated objectives of the Union is to work with the central bank to facilitate the smooth running of the market, ${ }^{38}$ which includes cooperating with the central bank in assessing the application of exchanger licenses ${ }^{39}$ and implementing its procedures such as ensuring that exchangers record their transactions. ${ }^{40}$ As explained in the following section, the central bank requires exchangers to possess a license to operate, and the Union helps ensure this rule is upheld. Thus, the bazaar sustains a level of autonomy from the state even while maintaining ties that facilitate cooperation.

Following the publication of the booklet containing the Statute in 2017, the central bank introduced a new article into its own regulation on money exchangers recognizing the Union as the "competent body" of money exchangers. ${ }^{41}$ This article recognizes the jurisdiction of the Union to operate according to its own administrative structure and to deal with disputes that arise internally. At the same time, the regulation also requires the Union to comply with the laws and regulation of the central bank, to report any breaches to the latter, and to only grant membership to exchangers who have obtained a license from the central bank (discussed below). The regulation thus affirms the complementary, yet competing, roles of the Union and the central bank. The latter not only confirms a zone of authority controlled by the former but also instructs the

34. Statute, Art. 34.

35. Statute, Art. 35.

36. Statute, Art. 7(4).

37. Statute, Art. 19.

38. Statute, Art. 2.

39. Statute, Art. 7(9).

40. Statute, Art. 7.

41. Muqarara Tanzim Fa-aliat hai Sarrafan va Fraham Konandagan Khidamat Puli (Regulation of the Activities of Money Exchangers and Money Service Providers), Doc. 1398/2019, Art. 56 (Money Exchanger Regulation). 
Union to report violations of laws and regulations, thereby claiming jurisdiction over such matters.

It bears mentioning that, while the Statute has introduced a level of formality and organization into the bazaar, the extent to which it directly regulates the affairs of exchangers should not be overstated. Unlike many professional codes of private associations that supply the substantive rules to be followed by its members, the Statute is mostly procedural, containing limited substantive directives. Its principal focus is on the organizational structure of the Union. Its substantive details are limited to the general roles and responsibilities of the Union and the Union's relationship with exchangers and government bodies. However, the Statute provides no direction on the substantive rules that should be followed by exchangers and other parties who transact within the bazaar. Despite the absence of formal rules prescribing such behavior, the Statute establishes an administrative body within the Union-the Conflict Commission-which is responsible for resolving disputes, a task that this commission has been successful in discharging. Thus, while the Statute represents a major transformation in the bazaar, it cannot be viewed as a total break from the past since informal legal practices continue to supply the meanings through which the Statute is understood and implemented.

\section{LICENSING THE BOUNDARIES OF THE UNION}

The efforts by exchangers to protect their interests by developing a Statute partially explains the ability of the bazaar legal system to maintain relative autonomy from the state. However, just as important has been the role of the government in both supporting the Union's jurisdictional claim over matters arising in the bazaar and controlling the licensing of exchangers, which has helped to ensure the cohesion of the bazaar. One of the reasons non-state legal systems collapse is their inability to maintain their boundaries (Clay 1997; Richman 2017; Grisel 2021).

As money exchanging often involves the handling of sizeable volumes of funds, the central banking authority has always had its eye on the ability to monitor these activities (Maimbo 2003). Particularly since money from the black market can cycle through the bazaar virtually undetected, monitoring would provide a means of identifying and potentially preventing such practices. In 2002, the central bank began registering the licenses of money exchangers (Bennett et al. 2003), ${ }^{42}$ and, in 2008, it enacted a regulation requiring exchangers to hold a government license. One of the challenges faced by the central bank was that, up until that point in time, it did not have a means of forcing exchangers to maintain licenses. While Afghanistan has had a central bank since the 1930s, only after 2001 did it develop many of its functions as a monetary authority. Up until 2001, the central bank was viewed as marginal, making it difficult to assert its authority over exchangers who possessed a long and established history in the country. Even after 2001, with government resources stretched and lacking authority, rigorous monitoring and enforcement of penalties against powerful exchangers, who played a crucial role in supporting the economy, was not a viable strategy. On another

42. Previous to this, licenses were registered by the Department of Foreign Relations. However, the requirement of registration itself was highly incomplete as indicated by the lack of personal data on exchangers. 
level, the central bank also faced the challenge of being able to assess the appropriate qualifications of an exchanger since exchangers themselves, rather than central bankers, would be most capable of making this judgment.

The approach taken by the 2008 regulation helped address both challengesnamely, the limited authority of the central bank and its limited capacity to gauge the skills of exchangers. The regulation specified that anyone seeking a license was required to have the reference of two businesspeople. ${ }^{43}$ This approach of requiring two guarantors shifted control over the licensing of new exchangers from the central bank back to the business community. The business community thus retained control over a significant part of the licensing process. This approach strengthened the authority of the central bank since businesses, in guaranteeing exchangers, ended up consenting to the requirements of the regulation. This approach also shifted the responsibility of assessing the qualification of an exchanger to the business community.

The 2008 regulation materialized in the period during which exchangers were working to consolidate their own set of rules for the bazaar. To maintain control over entry into the market, these exchangers made it a requirement for all exchangers to possess a valid license from the central bank, ${ }^{44}$ which in turn meant that new exchangers would need to be guaranteed by fellow businesses. In this way, exchangers were able to deploy central bank regulations to limit unlicensed exchangers, while the bank benefited from an uptake in licenses. As time progressed and the central bank increasingly benefited from working with exchangers, the bank began requiring that the guarantors be exchangers themselves (rather than any licensed business). ${ }^{45}$ As a result, whereas, in the past, membership into the profession was informally regulated by an exchanger's ability to acquire the requisite resources from their personal community and gain the trust of clients and fellow exchangers, the new Statute of the bazaar, as well as the central bank licensing regulations, made it a requirement that new exchangers be guaranteed by existing license holders, providing exchangers a high level of control over the composition of community membership.

The current composition of the bazaar is a direct result of the control held by incumbent exchangers. Exchangers consist of a small community whose membership is limited by those who are already members. Exchangers have an interest in denying membership to anyone who they perceive to be deceitful since the entire profession depends on people having trust in the community as a whole. New community members may also be a source of competition that may otherwise be avoided. Serving as guarantor is viewed as a serious role as it means that the exchanger is willing to put his own reputation on the line for another party: "It is very difficult for someone to guarantee you in Sarai Shahzada, without any close relationship and recognition. And it is clear to everyone that without any recognition nobody will dare to guarantee you because a guarantor has some responsibilities. ... If the exchanger runs off with money, the guarantor must bring him back to the Etihadiya and this is his responsibility." ${ }^{46}$

43. Regulation of the Islamic Republic of Afghanistan: Da Afghanistan Bank, 8-9 July 2008, Part B: Issuance of License, s. 1.2.1.

44. This is currently reflected in articles 7(10) and 8 of the Statute.

45. This later became a formal requirement in subsequent central bank regulations on money exchangers. See Money Exchanger Regulation, Arts. 8.1.9, 9.1.6.

46. Daanish (money exchanger), interview by the author in Kabul, Afghanistan, December 2017. 
Whether a guarantor bears financial responsibility for a deceitful exchanger is ambiguous. Exchangers across the market emphasized that "guarantors guarantee only an exchanger's name but not their property. ... Nobody will provide a guarantee for the money but some of the exchangers are guaranteeing only the names of other exchangers." 47 Neither the Statute nor the central bank regulations specifically hold exchangers responsible for the actions of the parties they guarantee. However, exchangers noted that the case could go to court where the "decision will be applied on the guarantor of the person and the court will order the person to pay the money for him." ${ }^{48}$ Furthermore, if the deceived party is powerful, he may demand repayment from the guarantor, and "he will pay him" to avoid problems. ${ }^{49}$ Thus, exchangers are cautious in providing guarantees, and if at any point they lose confidence in the party they have guaranteed, they may revoke their guarantee by reporting it to the Union (and the central bank). Obtaining a license requires strong personal ties with existing exchangers. While it promotes community cohesion, it also poses a significant barrier to entry for a party who may otherwise have the skills and finances to work as an exchanger but who lacks strong personal ties required to find a guarantor. ${ }^{50}$

The reliance by exchangers on licenses from the central bank gives the bank the authority to monitor the activities in the bazaar. Once a year, a group of inspectors from the central bank enters the bazaar to monitor exchangers. These inspectors ensure that exchangers have properly renewed their licenses, that they are bookkeeping their transactions in the ledgers provided by the central bank, and that sizeable transactions have been documented with all of the relevant information about their customers collected and reported. ${ }^{51}$ They also try to ascertain whether exchangers are engaged in any unauthorized activities. At this point, a game of cat and mouse begins. Both exchangers and the central bank depend on one another just as they also aim to assert and expand their authority. When the inspection team enters the bazaar, before commencing their work, they first visit the office of the Union to inform its members of their visit. As one central banker and previous member of the inspection team asserted: "This is not to take permission but rather to inform them that we are doing our work in the bazaar." 52 However, members of the Union perceive this visit differently: "They first come to the Union to get our permission. Then they start working." 53 Each side upholds a convenient interpretation that allows it to claim its authority. Regardless of who is more correct, one certainty rings true throughout the bazaar: "As soon as they [that is, the

47. Naeem (money exchanger), interview by the author in Kabul, Afghanistan, December 2017.

48. Khalil (executive of the exchanger Union), interview by the author in Kabul, Afghanistan, March 2018.

49. Nesar (money exchanger), interview by the author in Kabul, Afghanistan, January 2018.

50. This barrier is partly offset by market realities. A party is usually able to build social ties over time with an exchanger, up to a point where an exchanger is willing to guarantee them.

51. Money Exchanger Regulation, Art. 37 requires that transactions above 500,000 Afghanis (approximately US \$6,500) must be reported to the Afghanistan Financial Transactions and Reports Analysis Center of Afghanistan. According to Art. 34 of the Money Exchanger Regulation, exchangers must collect information on their customers. For transactions below 50,000 Afghanis, the name, address, and phone number of the customer should be collected. As the amount transacted increases, the exchanger should collect further information including their citizenship card, passport, driver's license, the source of funds, and the intended use of the funds.

52. Mir Jahan (DAB official), interview by the author in Kabul, Afghanistan, November 2017.

53. Naeem (money exchanger), interview by the author in Kabul, Afghanistan, December 2017. 
inspection team] enter, every shop knows they are here." ${ }^{54}$ In the time that it takes for the inspectors to climb the four flights of stairs to reach the office of the Union and deliver their entry pleasantries, every shop has swiftly stored away any documents they do not want noticed. One exchanger remarked: "I remove the laptop that I use for all of my transactions from the office table and leave only the transaction book." Another said: "My neighbor comes into my shop with some of his transaction books and asks me to hide them for him." 56 When the inspectors begin their work, exchangers have had ample time to prepare themselves.

Exchangers prepare themselves for these visits well in advance, often providing monthly records of their transactions to the central bank over the course of the year and maintaining a book of transactions specifically for inspectors. One exchanger explained the preparation that goes into visits by the inspectors:

We tell the DAB [that is, the central bank] that we have 2,100 hawala in one month. We report ten as being big and give the information to the DAB. We give this information monthly. For these [ten big transactions] we give the correct client information like passport or ID. The other 2,090 we don't need to report because they're small. For these, we write fake information in a book. Imaginary names and hawalas. We have two books, one book with the fake hawalas and another book that we use for business. Inspectors only see the fake book. In reality, we have maybe 3,000 hawala in one month, and much more than ten are big. ${ }^{57}$

By providing information on a monthly basis to the central bank on a number of hawala transactions, this exchanger avoided undue suspicion from inspectors, as his transactions fit within what inspectors would consider a "reasonable" level of activity. ${ }^{58}$ Nonetheless, the exchanger deliberately misrepresented the transactions carried out at his shop by underreporting the number of large transactions and providing a fabricated book of small transactions. In this way, the exchanger fulfilled the requirements of central bank inspectors while, at the same time, preventing those officials from being able to gauge the actual level of activity of his business and the identity of his clients. Exchangers are able to employ such strategies to maintain a level of independence from inspectors even while maintaining their government licenses that grant them permission to perform money-exchanging services.

The inspection team for its part seeks to maximize the effectiveness of its work by relying on the element of surprise. An inspector noted: "We may go from one shop on the first floor to a shop on the third floor next." 59 With some 400 shops in the bazaar and each inspection requiring ten to thirty minutes, the team may complete only twenty

54. Homayoun (money exchanger), interview by the author in Kabul, Afghanistan, March 2018.

55. Edris (money exchanger), interview by the author in Kabul, Afghanistan, January 2018.

56. Mashal (money exchanger), interview by the author in Kabul, Afghanistan, February 2018.

57 Abdul Ghafoor (money exchanger in Kabul, Afghanistan), phone interview by the author in the United Kingdom, March 2021. As discussed above, only "large" transactions need to be reported to the central bank.

58. I asked the exchanger why he did not simply say he had zero large transactions, to which he responded that inspectors would know he was lying, leading them to become suspicious of his transactions.

59. Mir Jahan (DAB official), interview by the author in Kabul, Afghanistan, November 2017. 
to thirty shops in one day and, thus, the full inspection of the bazaar takes close to two weeks. This is a long time for exchangers to keep their books hidden, and the random movement of inspectors between shops may catch some off-guard. The inspection team inevitably finds some breaches. Sometimes a license has lapsed, and other times an exchanger has not recorded or reported his transactions properly, and the inspection team may issue a warning or a fine to the offending party. The team also works with exchangers by providing advice on how to best maintain their records, revealing how their relationship with exchangers is not purely adversarial but also complementary. By the end of their inspection, the team can claim to have duly discharged its responsibility of monitoring the bazaar, while exchangers can likewise claim to have avoided the undo intrusion of the central bank. This game of outmaneuvering the other allows for both the exchangers and the inspectors to maintain their respective claims to authority at the borderlines where their respective legal systems come into contact with one another and the dominant authority of neither can be taken for granted.

The regulation of exchangers through central bank licenses brings into plain sight the role that is played by the state in constituting the boundaries of the bazaar. Studies in fragile settings tend to treat markets as "islands of order" that operate "in the absence of a bureaucratic state that provides such order" (Spector 2017, 2). The autonomous functioning of these communities is attributed to the absence of the state (Greif 1993; Richman 2017). Furthermore, existing studies posit that private communities risk collapsing once their boundaries come under pressure, whether from the growing presence of the state (Clay 1997; McMillan and Woodruff 2000) or the unregulated entry of newcomers (Woodruff 1998; Grisel 2021). By contrast, the licensing of money exchangers by the central bank allows exchangers to retain control over community membership. Eleanor Ostrom (1990) argues that states may assist legal ordering in private communities by assuming the costs of monitoring shared resources. The bazaar complicates this assertion by showing that the relationship between the state and a private community can be simultaneously collaborative and antagonistic. The monitoring of exchangers by the central bank infringes on their autonomy, even while exchangers depend on this same governmental body for licenses. For exchangers, the price of controlling the boundaries of their community is periodic interference by government officials in their affairs.

\section{FORMALIZATION OF THE CONFLICT COMMISSION}

\section{Structure of the Commission}

Prior to the emergence of the Union, no formalized process existed for the resolution of disputes. Parties sought to resolve problems informally through direct negotiations, sometimes calling upon respected friends and elders to intervene. The process had no regularity and thus would change between cases and individuals. Exchangers did recognize that courts were available as a potential venue to have a dispute resolved, but the prevailing attitude was that, if one were to go to court, "the solution is never 
solved" and the parties would be in "for a looooong ride." 60 As the number of exchangers in the bazaar grew and the volume and frequency of transactions increased, the community came under increasing pressure to find an expeditious means of resolving disputes between parties.

The emergence of the Conflict Commission, one of five standing commissions established by the Statute, introduced a level of regularity in the resolution of disputes. Prior methods of resolving conflicts relationally continue to be widely practiced. Parties still settle disputes between themselves or with the assistance of a respected friend. The addition of the Commission allows for parties to escalate their disputes internally within the bazaar by seeking the intervention of the Union, which is itself composed of exchangers. As a formalized dispute resolution mechanism, the Commission has altered the process through which disputes are resolved while also providing "considerable continuity in social values and concerns" (McConnachie 2014, 58).

The Conflict Commission consists of fifteen members along with one chair and two deputies. ${ }^{61}$ To reduce its load, the fifteen members are divided into three committees, each with five members, and each carrying out the same task of resolving cases. The stated duty of the Commission is to "find the solution to a legal conflict" based on the guidance of the "Chairman of the Commission, the regulations and customs of jirgas, and trade practices." 62 Beyond these vague instructions, the Statute does not specify the process of submitting complaints or any of the rules that should be applied in adjudicating cases. The Statute defines the general, administrative contours of the Commission without specifying the applicable procedural and substantive rules. The Commission could be considered as an "administrative bureaucracy," a term used by Kwai Hang Ng and Xin He (2017, 18; emphasis in original) to describe the structure of certain Chinese courts where "rules are only applied as to who should be in charge of making decisions ... rules decide who makes the decision, but not so much how the decision should be made or what the decision should be." As an administrative bureaucracy, the Commission provides a shell that is authorized by the Statute and backed by the legitimacy of the Union; however, its substantive contents must be supplied by its members who adjudicate the cases of other community members.

The lack of instruction seems intentional for two reasons. The first reason relates to the concerns raised by exchangers during the drafting of the Statute on the possible undue interference of the Union in their transactions. While a dispute resolution forum would hopefully facilitate business in the bazaar, its existence could be seen as infringing on the activities of some exchangers by creating normative expectations that did not exist previously. By minimizing the rules related to the Commission, drafters avoided potentially controversial and politically charged discussions that may have made it difficult to garner the agreement of all exchangers. Thus, instead of delineating specific rules, the Statute leaves it to the exchangers to decide on the precise procedural mechanisms for receiving, hearing, and disposing of disputes as well as the appropriate substantive rules to be applied. Elsewhere, an intentionally vague approach to legislating

60. Wahab (money exchanger), interview by the author in Dubai, United Arab Emirates, October 2017.

61. Statute, Art. 26.

62. Statute, Art. 27. 
has been deployed as a strategy to avoid contentious issues. Hanna Lerner's (2011) work on constitution-making in divided societies contends that drafters in such settings may intentionally leave certain provisions of law vague or incomplete to avoid politically charged and divisive issues. In East Timor, where dispute resolution authority rests with local community leaders, the government sought to assert its authority by establishing a process of electing those leaders, though allowing them to resolve issues according to their own rules (Swenson 2018). The bazaar's Statute similarly provides broad outlines of a dispute resolution mechanism but defers any choices on procedural and substantive rules to the exchangers themselves.

An alternative, more pragmatic reason may explain the vague rules associated with the Conflict Commission. Textual resources do not command significant authority amongst exchangers, reflecting their backgrounds and day-to-day dealings. Few exchangers have been formally educated, and many possess limited literacy. When asked about his educational background, one exchanger laughed out: "Of course, I didn't go to university - this [that is, the bazaar] has been my university." ${ }^{63}$ One learns the trade of money exchanging by spending extended periods with a more senior exchanger (often one's father or uncle), acquiring not only their knowledge but also their social capital - their network of customers and their reputation as a trustworthy person. While transactions are meticulously noted in accounting books and, increasingly, in computer excel files, few transactions involve written contracts or receipts since greater reliance is placed on social relations. ${ }^{64}$ Given the general preference for practice over text, a lengthy set of rules would be viewed as not only unnecessary but also undesirable and impractical. The vague provisions in the Statute on the rules of the Conflict Commission strike a balance between ensuring that exchangers retain control over internal affairs in the bazaar vis-à-vis the state and granting exchangers full flexibility to conduct the Commission as they deem appropriate.

\section{Bringing a Dispute before the Commission}

Disputes are heard in the main office of the Union on the top floor of the bazaar. This office possesses an unremarkable appearance with sofas along the walls and coffee tables spread out across the middle. Connected to the main office area is a smaller room with traditional seating mattresses (toshak) on the floor. Most disputes are heard in this adjacent room, with the committee members sitting in a circle alongside one of the disputant parties on the floor. ${ }^{65}$ The physical forum bears no resemblance to a courtroom but appears instead like a familiar domestic setting. While no statistics exist on the

63. Naeem (money exchanger), interview by the author in Kabul, Afghanistan, December 2017. None of the exchangers owning shops who I spoke to had university degrees. Some shop employees, usually in their early to mid-twenties, had degrees.

64. The issue of trust between exchangers and clients is explored in a forthcoming article of mine. See Choudhury, forthcoming.

65. Often, the committee hears from the parties one by one, so that the parties are not aggravated by each other's presence. 
volume of disputes processed by the Commission, it is the most active subcommittee of the Union, with several disputes being resolved each week. ${ }^{66}$

The functioning of the Commission depends on the willful participation of the parties. The primary beneficiaries of the Commission are exchangers facing problems with one another. The Commission has neither the power to compel parties to attend nor the ability to enforce its judgments. Parties must do this work themselves. As a small and close-knit community, exchangers understand that they will likely need to rely on others in the bazaar in the future. Negative rumors about a party unwilling to comply with a decision of the Commission may make others reluctant to deal with that exchanger. The threat of reputational damage and social ostracism is thus strong enough to ensure that parties participate in hearings and adhere to judgments. Furthermore, while an exchanger may be unhappy by the decision of the Commission, the prospects of a lengthy and costly legal dispute may be even more unappealing, and, thus, exchangers are often willing to swallow the costs and move forward. Discussions with numerous exchangers revealed the general procedure of raising a dispute: ${ }^{67}$

Step 1. Submitting a formal application by the claimant to the office of the Union, clearly stating personal identity, nature of the claim, and the opposite party.

Step 2. Reviewing the claim by the Union and sending it to the Conflict Commission if the claim is legal and logical.

Step 3. Assigning the case to one of the three committees by the chair of the Commission.

Step 4. Taking fingerprints and signatures of both the plaintiff and the defendant in order to ensure their compliance with the final ruling of the Commission.

Step 5. Reviewing and investigating the case through discussions, oral testimony, supporting documents, or whatever other resources that may be necessary for making the final decision. Step 6. Sending the decision of the Commission to the Union for signature by the president to make the decision final and binding.

These steps provide a general sense of the process involved, which has emerged as a commonly followed routine in dealing with disputes in the bazaar. Its regularity gives the process an air of authority by providing parties reasonable expectations of the steps involved. Nonetheless, this process is by no means applied uncompromisingly as its actual instantiations will deviate according to circumstances.

\section{Cases before the Commission}

The flexible application of procedural as well as substantive rules is best revealed by examining some of the disputes that come before the Commission. Three such cases are described here to provide a glimpse of dispute resolution in action.

66. This assessment is based on my own observations of the office of the Union. When I asked for estimates, several exchangers said fifteen to twenty disputes arise each day. However, this figure seemed to be a significant overestimate given my observation of the Union and also likely involved minor disagreements between exchangers, most of which never reached the Union.

67. These steps represent a general, recognizable template of procedures constructed by asking experienced exchangers to reflect on the process after the fact. 


\section{Case 1}

An exchanger, Matin, urgently needed $\$ 1,000$ for a transaction with a client but lacked the necessary capital, and so he borrowed this amount from Saifullah, another exchanger, agreeing to return the amount in one day. However, after three days, Matin had still not returned the amount. Saifullah thus referred the case to the Union, and the president talked with both Matin and Saifullah. Upon confirming that the amount was outstanding, the president scolded Matin and orally ordered that he return the amount immediately. The case was not referred to the Conflict Commission. After one day, Matin returned the full amount. Saifullah stopped loaning money to Matin for several months, but eventually resumed doing so.

Case 1 reveals that disputes may be resolved at any point and need not proceed to the Conflict Commission. The procedures are only followed insofar as they contribute to the resolution of the dispute. A deviation presents no issue if it can help expedite a resolution of the conflict. In this case, the president of the Union was immediately able to dispose of the case without involving the Commission. Though the parties did not resort to the Commission, by turning to the Union, the parties signaled an escalation in the intensity of the dispute. In receiving cases and inquiring about problems, the president not only diffuses conflicts but also reaffirms the Union's authority to carry out this role. The ability to question the parties "reasserts its jurisdiction, reinforces the atmosphere of officiality, and claims to represent the concerns of the community about the eventual consequence of the relationship" (de Sousa Santos 1977, 46). By turning to the Union, exchangers are confirming their commitment to the Union and its authority to resolve disputes. The more that exchangers turn to it when disputes arise, the more the Union gains "cognitive legitimacy"- that is, it is viewed as the natural and obvious forum for dealing with such disputes (Suchman 1995, 577). Throughout the bazaar, when asked how problems were resolved, exchangers consistently responded that the Union resolves their disputes, suggesting its widespread approval.

\section{Case 2}

An exchanger, Omid, was the owner of a house and allowed his friend, Ali, to live in it. Because of their close friendship, Omid did not take rent from him, and this arrangement continued for ten years. Omid previously worked as a property dealer, which is how he acquired several houses through shara'i (customary) property deeds. After ten years, Omid asked Ali to vacate the house as he needed to sell the house to repay a loan. However, at that point, Ali claimed that he had purchased the house and that he was the rightful owner. Omid thus brought the matter to the Union. The Commission held a jirga to hear the case in the presence of both the exchanger and the tenant; however, during this session, Omid felt that the chair was being biased in favor of Ali because of an alleged pre-existing relationship. Omid thus left the jirga without the case being resolved and approached another respected exchanger, Jawad, who was also working in the bazaar. He explained his case to Jawad, stating that he owned the customary deeds to the house. The jirga reconvened its session, and this time Jawad also participated. After hearing all of the parties, including Jawad, the Commission ruled 
that Ali should vacate the property as soon as possible. The decision was written and signed by the president of the Union.

The jurisdiction of the Commission is porous and flexible, being open to parties who believe they can benefit from its services. While disputants are primarily exchangers, they may also involve non-exchangers and may concern a matter not directly related to the bazaar. In Case 2, the Commission was willing to hear the case as it dealt with a problem of one of its exchangers, and it felt that it had the ability to resolve the matter. By expanding its jurisdiction, the Commission reinforced its ability to resolve disputes, thereby legitimizing its authority both in the bazaar and across society, while the parties benefited from an expeditious process supported by respected members of society. Though a dispute may not deal directly with a transaction in the bazaar, it normally has some level of connection with the bazaar since otherwise the parties would not feel bound by its decision. A non-exchanger cannot be compelled to attend through the threat of reputational damage and thus must agree to participate in the process. Ali was not available to explain why he participated in the process despite not being a money exchanger himself; hence, one can only speculate on the reasons. According to Jawad, Ali knew members of the committee and thus may have hoped to have the decision go in his favor for this reason. Alternatively, Ali may have hoped to do business with an exchanger in the future and thus did not want his reputation affected. However, mostly likely, he participated because, while there existed the possibility of a decision in his favor, a decision against him would not be decisive. The Commission could not compel him to vacate. Omid would still have to approach the community elders in his area with the decision and seek their assistance in evicting Ali. Otherwise, Omid could try to work out a compromise with Ali or take the matter to court (using the written decision as persuasive evidence). In any case, Ali still retained leeway in being able to negotiate an outcome in his favor, even if partially. When I asked Jawad who got the house in the end, Jawad shrugged his shoulders, saying: "We decided against Ali so he should leave. The Commission did its job." ${ }^{\circ}$ The Commission has done all it could do-namely, render a decision.

Like Case 1, Case 2 highlights the flexible procedures that are applied by the Commission. No clear procedural rules exist on the participation of outside third parties when disposing of a case. The testimony of a third party may be welcomed if it can bring about greater clarity or a resolution to the dispute. In this regard, rules should be viewed as "a loosely constructed repertoire rather than an internally consistent code" since they may be manipulated and selectively applied with the goal of arriving at a final outcome (Comaroff and Roberts 1981, 18).

\section{Case 3}

A client walked into Hikmatullah's shop asking him to safekeep $\$ 6,450$. The client was planning to get smuggled to Europe and only wanted the money released to the smuggler upon his arrival. Hikmatullah accepted the funds, and his shop clerk drew up a contract stating: "I take $\$ 6,450$ from [client] for fifteen days. During the fifteen

68. Jawad (money exchanger), interview by the author in Kabul, Afghanistan, December 2019. 
days, if [client] gives me permission, I will give the money to [smuggler]. If no permission is given, then after the fifteen days, I will return the money to [client]." After twelve days, the smuggler came to the office and asked for the money, saying that he completed his job. The shop released the funds to the smuggler. However, after fifteen days, the client returned to the shop to reclaim his funds claiming that the smuggler failed to fulfill his role. The case was referred to the Commission. A group of seven committee members - themselves exchangers - investigated the matter, hearing the parties in turn. The exchanger claimed that the client was colluding with the smuggler and thus engaging in fraudulent activities, whereas the client argued that the exchanger had not followed the terms of the agreement. The Commission ruled that the shop should return the full amount $(\$ 6,450)$ back to the client. The client threatened to go to court if the shop did not return the full sum. The shop returned the full sum to the client. Hikmatullah remarked that if the customer were to lodge a court case against him, it would greatly damage his reputation, which was far worse than a payout of $\$ 6,450$.

One of the reasons that decisions of the Union are followed is the reputational damage that a recalcitrant party may suffer. In Case 3, the client as a non-exchanger expressed his willingness (even if disingenuous) to engage in court proceedings. In this regard, the client was able to engage in strategic forum shopping, choosing the option most likely to provide the desired outcome (von Benda-Beckmann 1981). The client was able to utilize the Commission to attain a positive outcome quickly and cheaply. Reputational damage would only be incurred by the exchanger, and, thus, he may find himself in a particularly precarious situation when faced with a customer willing to exploit this imbalance. As long as a dispute is resolved by the Commission, an exchanger will generally suffer minimal reputational damage as the outcome of disputes are not actively broadcast or particularly sought out in the market. ${ }^{69}$ As one exchanger remarked: "The Commission hears so many disputes. We don't have time to learn about all of them. We're too busy."70 Conversely, if an exchanger refused to adhere to a decision of the Commission, he would risk reputational damage since the news of his recalcitrance would spread more quickly across the bazaar as it represents a deviation from the expected behavior of an exchanger. Furthermore, if a dispute escalates to legal proceedings, this news will likely spread because of the low frequency of such incidents, further damaging the exchanger's reputation.

Case 3 also highlights the blurred line between licit and illicit transactions in the eyes of the Commission. Parties would generally be hesitant about pursuing a case in the state courts where the underlying transaction involved human smuggling (calling to question the veracity of the claimant's threats in Case 3 to go to court) since both parties risk being punished. ${ }^{71}$ The Commission has greater flexibility to deal with such matters. By focusing on the wording of the contract, the Commission can maintain a convenient separation between the contract and the underlying transaction, even if all parties, including the members of the Commission, are aware of the true nature of the transaction. Nonetheless, the degree of illicitness of the underlying transaction

69. While a decision may not be openly broadcast, information on the outcome may still spread across the bazaar since no rule exists on keeping decisions private.

70. Hafiz (money exchanger), interview by the author in Kabul, Afghanistan, April 2018.

71. Law Prohibiting Human Trafficking and Migrant Smuggling, Law no. 1395/11/10 (2017) (Afghanistan) 
is also a factor. While the Commission may be willing to hear an agreement where smuggling is involved, it will not hear disputes involving illicit drug money. Parties would also be unlikely to bring such disputes before the Commission since a party caught dealing with such funds would likely be arrested by the police and have their shop closed. ${ }^{72}$ Limits thus exist on the extent to which the Commission can operate without the involvement of the state authorities.

The principal success of the Commission can be attributed to its ability to expeditiously resolve disputes. In many settings, private associations provide a quick and cheap alternative to courts (Bernstein 1992, 2001; Richman 2006). With exchangers, the timing of transactions is an integral element of their business. The fluctuations in currency prices each minute can provide an opportunity for an exchanger to reap a sizeable profit. Exchangers thus need disputes resolved swiftly so that they can recuperate outstanding funds (like in Case 1) and move forward. Moreover, exchangers depend not only on their own funds but also on strong working relations with one another in the bazaar since collaboration creates profitable opportunities. The Commission helps neutralize disputes while maintaining the reputation of the parties, thus allowing disputants to continue working with one another (if not immediately, then possibly after the passage of time once emotions have settled and trust is regained).

Furthermore, exchangers view the Commission as something that is "theirs." Its adjudicating members are themselves exchangers, all aware of the importance of quickly resolving disputes rather than becoming bogged down in cumbersome rules and formalities. The Commission allows for disputes to remain within the internal control of the Union. Parties unhappy with an outcome can directly talk to the exchangers involved in adjudicating the case (no rules or expectations prevent such behavior). In Case 3, following the decision by the Commission to hold the exchanger liable for the full amount, a (university-educated) employee of the exchanger's shop named Hamid confronted the president of the Union to express his frustration about a process that vindicated the fraudulent—as he saw it—activities of customers. His ability to vocalize his opinion and be a part of the ongoing life of the Union helped neutralize some of the damage he felt as part of the losing party. While unhappy about the outcome, Hamid was aware of the entire process that played out from start to finish and could have become active in the life of the Union in the future if he wanted to seek changes. He thus retained a level of agency over his circumstances despite his losing position, which can be contrasted with the opaqueness and unpredictability of state legal proceedings (Swenson 2017). Furthermore, the Commission constitutes one of the integral functions of the Union, which protects the collective interests of all exchangersincluding the aggrieved ones-against the state. Thus, the proverb, "me against my brother, me and my brother against our cousin, the three of us against the world" conveys the attitude that exchangers hold towards the Commission (Thompson 2011).

The flexible application of procedural and substantive rules shows how the Conflict Commission does not represent a break from past practices but, rather, significantly draws from those practices. The members of the Commission are not legally trained persons but, instead, money exchangers who are all peers of the impugned

72. Law on Prevention of Money Laundering and Proceeds of Crimes, Law no. 05/01/1393 (2014) (Afghanistan) 
parties. The members sit in a circle on the ground or on chairs when listening to disputants. They communally discuss the matter amongst themselves and with the parties and may be swayed by the testimonies of witnesses or respected persons. Amongst the many disputes that come before the Commission, only one principle remains constant - finding a solution to the underlying dispute. As John Comaroff and Simon Roberts $(1981,14)$ write, "rules may themselves be the object of negotiation and may sometimes be a resource to be managed advantageously." Rules serve as tools that may aid in reaching that solution or may be put aside if deemed an impediment.

In this way, the Commission, while being cast outwardly as a formalized adjudicative body of the Union, functionally resembles traditional shuras and jirgas found throughout Afghan society. Like a shura or jirga, it works toward reaching a solution that helps maintain stability within the community. However, this approach does not imply that cases will always involve a compromise by both sides (in all three cases above, one winning party reaped the full benefit). Because the adjudicating members are all exchangers and understand the role of money in the affairs of individual exchangers, they are reluctant to lessen the obligation of debtors, as this would interfere with the very business of money exchanging. Rather, keeping the peace often means affording parties their full right, as otherwise the Commission would signal to participants in the bazaar than any party could obtain a reduction in its obligation by raising a complaint.

The Commission helps reveal how legal transformations within a private community may gain legitimacy amongst its members. Both the formalization of rules in the bazaar and the demarcation of its boundaries through central bank licenses may be necessary conditions for preserving the autonomy of the bazaar. However, meeting the sufficiency condition requires that the transformations of the bazaar's legal system be legitimized by its members. One reason a community may collapse is because its social norms, which provide stability, may also be a source of inertia if they fail to keep pace with changing societal circumstances (Clay 1997; Richman 2017; Grisel 2021). The few studies that shine a light on the conditions under which private communities will emerge do not provide an explanation of the process of norm legitimation within a private community (Grossman 2021).

Mark Suchman's (1995) typology of institutional legitimacy is instructive in this regard. The workings of the Commission show that its substantive rules rely on the long-standing norms of exchangers and thus are consistent with their mores and conventions, which may be referred to as "normative legitimacy." Furthermore, newly formalized rules on the administrative running of the Commission provide exchangers with tangible benefits, which may be termed "pragmatic legitimacy"—namely, a forum that efficiently resolves disputes without government interference and that allows exchangers to be a part of the process at every stage, thereby granting them agency. Because of its widespread support amongst exchangers, the Commission is viewed as the natural and obvious forum for dispute resolution if a problem in the bazaar requires the intervention of third-party arbitrators-it has "cognitive legitimacy." The Commission reveals how legal transformations may be legitimized through a combination of continuity and change-reliance on the widespread support of prior norms alongside the introduction of new rules that provide discernable gains. 


\section{COURTS AS A FINAL RESORT}

While the Commission is available to parties seeking to resolve their disputes, state courts remain available to any aggrieved party (Rahimi 2019). The Union does not deny the jurisdiction of courts nor its ability to deal with disputes. Rather, the Commission is viewed as a more practical, expeditious way of resolving disputes and allows for the parties to benefit from adjudicators who themselves are area experts and who understand the significance of having a dispute quickly resolved. One instance where an exchanger may seek the assistance of the court is when an exchanger in the bazaar closes his business-the classical "end-game" problem in game theoretic terms (Landa 1981). The Commission is effective because the parties are repeat players-that is, parties who repeatedly interact with one another and who wish to avoid the sanctions of reputational damage and social ostracism. However, when an exchanger discontinues his business and leaves the bazaar, he no longer has an incentive to submit himself to the jurisdiction of the Commission or adhere to its outcome. In such instances, the court may be the only available forum for an exchanger. Stewart Macaulay's (1963) study of Wisconsin businesses showed that, while parties may shun the use of courts and instead prefer to resolve disputes relationally, when the relationship between the parties is at an end, the wronged party is more likely to threaten legal proceeding through the courts.

As an exchanger named Siyar explained, "most of the time disputes between exchangers are resolved through the Union. If disputes between them are not solved through the Union, then they will go to court." ${ }^{73}$ He continued by describing a dispute that arose between two exchangers. One of them had invested $\$ 500,000$ in the other. One day, the exchanger holding these funds came under government scrutiny for alleged illegal activities, which for undisclosed reasons made him unable to return the funds. Subsequently, this exchanger closed his shop in the bazaar. Since he no longer operated in the market, he had no incentive to appear before the Commission. Thus, the first exchanger commenced legal proceedings to reclaim his funds. The court maintains jurisdiction to hear cases involving exchangers, and exchangers may pursue this option once the forms of coercion available through the bazaar legal system cease to be effective. Even in those instances where the Union is unable to resolve the dispute, it may intervene to provide relief to the aggrieved parties in other ways: "The Union allowed him to take the shop [of the exchanger who did not return the funds]. So he took the shop instead of his money. If the second exchanger finds the money and convinces the first exchanger to take back the money, he may get his shop back." 74

As this instance shows, while exchangers may turn to courts because of the inability of the Commission to resolve a dispute, the Union will not necessarily absolve itself of all responsibility. The Union can propose an array of creative options that may resolve a problem or provide an interim solution. The jurisdiction of the Union and the court are thus not mutually exclusive but, rather, may overlap, allowing for

73. Siyar (money exchanger in Kabul, Afghanistan), phone interview by the author in the United Kingdom, June 2020.

74. Wasim (money exchanger in Kabul, Afghanistan), phone interview by the author in the United Kingdom, November 2020. 
aggrieved parties to engage in strategic forum shopping if any one forum is unable to provide an adequate outcome (von Benda-Beckmann 1981; Tamanaha 2008; McConnachie 2014).

\section{CONCLUSION: WHY DID FORMALIZATION SUCCEED?}

While a variety of studies detail the functioning of non-state legal systems, usually explaining their existence through the efficiency savings gained by the parties, they often provide static accounts of how such systems operate (Landa 1981; Ellickson 1991; Bernstein 1992; Greif 1993; West 1997; Ranasinghe 2014). In the cases where a dynamic element is included to track the functioning of the non-state legal system over time, the result is normally either the deterioration of the system (Greif 2006; Richman 2017; Grisel 2021) or its integration into the state legal system (Feldman 2006). The money bazaar reveals the ability of an informal, non-state legal system to maintain its operational autonomy during a period of state encroachment by mimicking the state legal system and formalizing its own operating structure. The community of exchangers has transformed from operating under an informal structure to hosting a centralized administrative body, including its own dispute resolution mechanism. The notion of formalization here does not refer to the integration of non-state law into the state legal system, as Hernando De Soto (1989) recommended in his study of the Peruvian informal economy, but, rather, the regularization rules and social structures. The formation of the Union and Conflict Commission represents the regularization of the bazaar legal system rather than its integration into the workings of the state legal system.

The question remains as to why the bazaar has been so successful in transforming into a formalized, non-state legal system. Five factors help explain this success. First, the process of transformation was entirely internally driven. No outside body, whether the state or otherwise, initiated the efforts to develop a codified Statute and centralized, administrative unit within the bazaar. These efforts were championed by the exchangers themselves as they sought to protect their market from the external and internal pressures that threatened to undermine it. The initiation of these efforts by the exchangers themselves helped overcome some of the suspicion of introducing change, as many exchangers would otherwise be wary about changes in the bazaar that may affect their activities. Exchangers were involved in the process of developing the Statute from start to finish, and all members of the bazaar, including those not leading these efforts, had the opportunity to participate in its development. The relatively small size of the bazaar with approximately four hundred shops meant that each shop was able to directly interact with the administration, even challenging certain aspects of its operations, if the need arose.

This internal process of transformation was also influenced by informal hierarchies that exist amongst exchangers (Sagy 2011). Those spearheading the efforts to develop the Statute were experienced exchangers who had been operating for decades in the bazaar, even during the reign of the Taliban regime (and some even prior to that). While the bazaar consisted of a mix of both long-standing and new exchangers, the former were particularly attune to the changes taking place within society and their 
possible consequences for the entire market in the foreseeable future. Furthermore, these experienced exchangers wielded significant respect, as their years in the market evidenced their ability to weather market contingencies, and, thus, their calls to form a centralized administrative body to protect the autonomy of the bazaar played a crucial role in garnering widespread support for the Statute.

Second, exchangers generally understood that a centralized body would be capable of protecting their interests. As the entire enterprise of money exchanging depends on the public viewing exchangers as trustworthy, a centralized body could help prevent deceptive exchangers from using the reputation of other exchangers to deceive customers, thereby damaging the image of the bazaar. Furthermore, money exchanging can be considered a privileged trade since those in the profession usually possess significant wealth and a rich set of social ties. Unimpeded access into the profession could affect the prestige of the incumbent exchangers. A union allowed the exchangers to maintain their privileged position by vesting them with control over membership into their community. Finally, a union could protect against outside interference by the state, thus allowing exchangers to conduct themselves on their own terms.

Third, formalization helped define the boundary between the bazaar and the state, allowing for the bazaar to operate more effectively within its boundaries as well as alongside government institutions. The Statute breathed life into the Union and provided it with the authority and jurisdiction to deal with matters internal to the bazaar, including dispute resolution. The revision and subsequent confirmation of the Statute by government officials further affirmed the jurisdiction of the Union, while also impliedly placing a limit on the government's jurisdiction on those matters. The state in turn benefited from the greater authority of its own presence in the market since the successful functioning of the Union depended on the licensing of exchangers by the central bank. Thus, defining the boundary between the bazaar and state not only neutralized tensions between the two but also made cooperation more feasible. However, this boundary is also characterized by ambiguity, such as the extent to which central bank inspectors may monitor the activities of exchangers. Maintaining this zone of ambiguity allows for each to claim its dominant authority without the need to decisively resolve the matter in favor of one or the other.

Fourth, the presence of the Statute and the Union reinforces a sense of community amongst a close-knit group of actors. Exchangers viewed the Statute as "their" law and overwhelmingly held the Union in positive esteem, as it operated "solely for the benefit of exchangers."75 The Union organizes events that reinforce social ties between exchangers, such as the celebration of religious events in the bazaar, blood drives for the public, and communal prayers when a prominent member of the bazaar or society has passed away. As Tom Tyler $(2006,173)$ writes, "people value identification with social groups" as they "provide a source of resources, self-knowledge, self-identification, and social reward," allowing members to "develop shared norms and patterns or reciprocity." A sense of community amongst exchangers promotes shared conventions, thereby strengthening cooperation in the course of business.

Fifth, formalization does not represent a rupture from the past but, rather, the transformation of past norms and practices into new forms. Part of the success of

75. Edris (money exchanger), interview by the author in Kabul, Afghanistan, January 2018. 
the Conflict Commission rests in its ability to integrate existing norms and practices into a new adjudicative body. Though it represents a formalized institutional body within the bazaar, the Commission relies on the informal practices that have long permeated the bazaar, including social networks that regulate the behavior of exchangers through the dual threats of reputational damage and social ostracism (Aviram 2003). As Roderick Macdonald $(2013,316)$ writes, these "informal, unwritten rules are significant not just because they are evidence of the 'law in action' but also because they are resources from which explicit, written rules typically draw their power and content." Informal norms infuse meanings into everyday actions in the bazaar and take solid form when appropriated by the Commission. While the Statute may breathe life into the formal structure of the Commission, this structure gains currency from the informal normative practices of the bazaar. The ability of the Commission to operate like a shura or jirga facilitates the continuance of uncodified, social practices that benefit from widespread approval amongst exchangers.

Nonetheless, the precarious life of the bazaar is played out everyday, as tensions come from many directions. An ever-changing state is always liable to introduce new regulations that may undermine the ability of exchangers to cooperate. Alternately, an excess of deceptive behavior amongst exchangers beyond a certain threshold could also risk collapsing the bazaar due to a loss of trust. Criminality remains yet another problem in recent years, as exchangers and their families have increasingly become the target of criminal gangs (Nordland and Abed 2019). Will these tensions bring about the eventual demise of the bazaar? While its future remains uncertain, its recent past reveals its ability to transform by creatively appropriating and re-institutionalizing legal practices from the state to consolidate its own functions. Its ability to innovate is thus fundamental to the way it operates. This transformative capacity will play an increasingly important role in the coming decades as the bazaar adapts to new changes from not only a changing state but also changing economic conditions at the local, regional, and transnational levels. By tracking the transformations of the legal system of Kabul's central money bazaar over the past two decades, this article has demonstrated that even in a fragile setting like Afghanistan, where the state lacks many of its functionalities, a private community may be able to maintain an autonomous legal system not by opting out of the state but, rather, by relying on it.

\section{REFERENCES}

Ahmed, Faiz. 2007. "Shari'a, Custom, and Statutory Law: Comparing State Approaches to Islamic Jurisprudence, Tribal Autonomy, and Legal Development in Afghanistan and Pakistan." Global Jurist 7, no. 1: 1-54.

Archer, Margaret S. 1996. Culture and Agency: The Place of Culture in Social Theory. 2nd ed. Halifax, UK: Cambridge University Press.

Atkinson, Rowland, and John Flint. 2001. Hidden and Hard-to-Reach Populations: Snowball Research Strategies. Social Research Update Issue no. 33. Guildford, UK: Department of Sociology, University of Surrey.

Aviram, Amitai. 2003. "Regulation by Networks." Brigham Young University Law Review 2003, no. 4: $1179-1238$.

Banakar, Reza. 2011. "The Sociology of Law: From Industrialization to Globalization." University of Westminster School of Law Research Paper no. 11-03. 
Barfield, Thomas. 2008. "Culture and Custom in Nation-Building: Law in Afghanistan." Maine Law Review 60, no. 2: 347-73.

Bennett, A. B. de Schaetzen, R. van Rooden, L. Dicks-Mireaux, F. Fischer, and T. Kalfon. 2003. Islamic State of Afghanistan: Rebuilding a Macroeconomic Framework for Reconstruction and Growth. Washington, DC: International Monetary Fund.

Bernstein, Lisa. 1992. "Opting Out of the Legal System: Extralegal Contracting in the Diamond Industry." Journal of Legal Studies 21: 115-57.

. 1996. "Merchant Law in a Merchant Court: Rethinking the Code's Search for Immanent Business Norms." University of Pennsylvania Law Review 144: 1765-1821.

. 2001. "Private Commercial Law in the Cotton Industry: Creating Cooperation through Rules, Norms, and Institutions." Michigan Law Review 99, no. 7: 1724-90.

Biernacki, Patrick, and Dan Waldorf. 1981. "Snowball Sampling: Problems and Techniques of Chain Referral Sampling." Sociological Methods and Research 10, no. 2: 141-63.

Bizhan, Nematullah. 2018a. "Aid and State-Building, Part II: Afghanistan and Iraq." Third World Quarterly 39, no. 5: 1014-31.

- 2018b. Aid Paradoxes in Afghanistan: Building and Undermining the State. Oxford: Routledge.

Choudhury, Nafay. 2014. "Pluralism in Legal Education at the American University of Afghanistan." Suffolk Transnational Law Journal 37, no. 2: 249-88.

— 2017. "Revisiting Critical Legal Pluralism in Afghanistan: Normative Contestations in the Afghan Courtroom." Asian Journal of Law and Society 4: 229-55.

—. 2021. "The Circulation of Informal Trade Credit (Ograyi) in Afghanistan." Asian Journal of Law and Society 8: 1-29. https://doi.org/10.1017/als.2020.58.

—. Forthcoming. "Transacting on Trust: The Regulation of Trade Credit by Afghanistan's Money Exchangers." Transnational Law and Contemporary Problems.

Chua, Lynette J. 2015. "The Vernacular Mobilization of Human Rights in Myanmar's Sexual Orientation and Gender Identity Movement." Law EF Society Review 49, no. 2: 299-332.

Clay, Karen. 1997. "Trade without Law: Private-Order Institutions in Mexican California." Journal of Law, Economics, and Organization 13, no. 1: 202-31.

Coase, R. H. 1937. "The Nature of the Firm." Economica 4: 385-405.

Coleman, James S. 1988. "Social Capital in the Creation of Human Capital." American Journal of Sociology 94: S95-S120.

Comaroff, John L., and Simon Roberts. 1981. Rules and Processes. Chicago: University of Chicago Press.

Coutin, S. B., and V. Fortin. 2015. "Legal Ethnographies and Ethnographies of Law." In Handbook of Law and Society, edited by A. Sarat and Patricia Ewick, 71-84. Oxford: Wiley \& Sons.

Creutzfeldt, Naomi, Marc Mason, and Kirsten McConnachie, eds. 2019. Routledge Handbook of SocioLegal Theory and Methods. Abingdon, UK: Routledge.

De Soto, Hernando. 1989. The Other Path: The Invisible Revolution in the Third World. New York: Harper and Row.

De Sousa Santos, Boaventura. 1977. "The Law of the Oppressed: The Construction and Reproduction of Legality in Pasargada." Law \& Society Review 12, no. 1: 5-126.

- 1995. Toward a New Common Sense: Law, Science and Politics in the Paradigmatic Transition. New York: Routledge.

Dixit, Avinash K. 2004. Lawlessness and Economics. Princeton, NJ: Princeton University Press.

Durkheim, Emile. 1982. The Rules of Sociological Method: And Select Texts on Sociology and Its Method. Translated by W. D. Halls. London: Macmillan.

Ellickson, Robert. 1991. Order without Law: How Neighbors Settle Disputes. Cambridge, MA: Harvard University Press.

Englund, H. 2006. Prisoners of Freedom: Human Rights and the African Poor. Berkeley: University of California Press.

Fafchamps, Marcel. 1996. "The Enforcement of Commercial Contracts in Ghana." World Development 24, no. 3: 427-48.

- 2004. Market Institutions in Sub-Saharan Africa. Cambridge, MA: MIT Press. 
Feldman, Eric A. 2006. "The Tuna Court: Law and Norms in the World's Premier Fish Market." California Law Review 94, no. 2: 313-69.

Flood, John. 2005. "Socio-Legal Ethnography." In Theory and Method in Socio-Legal Research, edited by Reza Banakar and Max Travers, 1-26. Oxford: Hart Publishing.

Fry, Maxwell J. 1974. The Afghan Economy: Money, Finance, and the Critical Constraints to Economic Development. Leiden: Brill.

Garth, B. G., and A. Sarat. 1998. "Studying How Law Matters: An Introduction." In How Does Law Matter?, edited by B. G. Garth and A. Sarat. Evanston, IL: Northwestern University Press.

Geertz, Clifford. 1973. The Interpretation of Culture. New York: Basic Books.

Giddens, Anthony. 1986. The Constitution of Society: Outline of the Theory of Structuration. Cambridge, UK: Polity.

Gillespie, John, and Pip Nicholson. 2012. "Taking the Interpretation of Legal Transfers Seriously: The Challenge for Law and Development." In Law and Development and the Global Discourses of Legal Transfers, edited by John Gillespie and Pip Nicholson, 1-26. Cambridge, UK: Cambridge University Press.

Gluckman, Max. 1973. The Judicial Process among the Bartose of Northern Rhodesia. Manchester: Manchester University Press.

Greif, Avner. 1993. "Contract Enforceability and Economic Institutions in Early Trade: The Maghribi Traders' Coalition." American Economic Review 83: 525-48.

. 2006. Institutions and the Path to the Modern Economy: Lessons from Medieval Trade. Cambridge, UK: Cambridge University Press.

Griffiths, John. 1986. "What Is Legal Pluralism?" Journal of Legal Pluralism and Unofficial Law 24: 1-55.

Grisel, Florian. 2021. "How Migrations Affect Private Orders: Norms and Practices in the Fishery of Marseille." Law Eु Society Review 55, no. 1: 177-202.

Grossman, Shelby. 2021. The Politics of Order in Informal Markets: How the State Shapes Private Governance. Cambridge, UK: Cambridge University Press.

Hertogh, Marc, ed. 2008. "What Is Non-State Law? Mapping the Other Hemisphere of the Legal World." In International Governance and Law, edited by Hanneke van Schooten and Jonathan Verschuuren. Northampton, MA: Edward Elgar.

- 2009. Living Law: Reconsidering Eugen Ehrlich. Oñati International Series in Law and Society. Oxford: Hart Publishing.

Higgins, Andrew. 2010. "In Afghanistan, Signs of Crony Capitalism." Washington Post, February 22. http://www.washingtonpost.com/wp-dyn/content/article/2010/02/21/AR2010022104317.html? sid $=$ ST2010090107315.

Katz, Michael L., and Carl Shapiro. 1994. "Systems Competition and Network Effects." Journal of Economic Perspectives 8, no. 2: 93-115.

Khan, Hamid M. 2015. Islamic Law, Customary Law, and Afghan Informal Justice. Washington, DC: United States Institute of Peace.

Kurkchiyan, Marina. 2009. "Russian Legal Culture: An Analysis of Adaptive Response to an Institutional Transplant." Law EO Social Inquiry 34, no. 2: 337-64.

Landa, Janet T. 1981. "A Theory of the Ethnically Homogeneous Middleman Group: An Institutional Alternative to Contract Law." Journal of Legal Studies 10, no. 2: 349-62.

Lerner, Hanna. 2011. Making Constitutions in Deeply Divided Societies. Cambridge, UK: Cambridge University Press.

Macaulay, Stewart. 1963. "Non-Contractual Relations in Business: A Preliminary Study." American Sociological Review 28, no. 1: 55-67.

Macdonald, Roderick A. 2013. "Custom Made-For a Non-Chirographic Critical Legal Pluralism." Canadian Journal of Law and Society 26, no. 2: 301-27.

Maimbo, Samuel Munzele. 2003. "The Money Exchange Dealers of Kabul: A Study of the Hawala System in Afghanistan." World Bank Working Paper no. 13.

Marsden, Magnus. 2015. "From Kabul to Kiev: Afghan Trading Networks across the Former Soviet Union." Modern Asian Studies 49, no. 4: 1010-48.

. 2016. Trading Worlds: Afghan Merchanges across Modern Frontiers. London: C. Hurst \& Company. 
2018. "Beyond Bukhara: Trade, Identity and Interregional Exchange across Asia." History and Anthropology 29, no. S1: 84-100.

Massoud, Mark Fathi. 2013. Law's Fragile State: Colonial, Authoritarian, and Humanitarian Legacies in Sudan. New York: Cambridge University Press.

McConnachie, Kirsten. 2014. Governing Refugees: Justice, Order and Legal Pluralism. New York: Routledge. https://www.routledge.com/Governing-Refugees-Justice-Order-and-Legal-Pluralism1st-Edition/McConnachie/p/book/9780415834001.

McMillan, John, and Christopher Woodruff. 1999. "Dispute Prevention without Courts in Vietnam." Journal of Law, Economics, and Organization 15, no. 3: 637-58.

—. 2000. "Private Order under Dysfunctional Public Order." Michigan Law Review 98, no. 8: 2421-58.

Merry, Sally Engle. 1988. "Legal Pluralism." Law Eु Society Review 22, no. 5: 869-96.

Michaels, Ralf. 2005. "The Re-State-Ment of Non-State Law: The State, Choice of Law, and the Challenge from Global Legal Pluralism." Wayne Law Review 51: 1209-59.

Moore, Sally Falk. 1973. "Law and Social Change: The Semi-Autonomous Social Field as an Appropriate Subject of Study." Law $\mathcal{G}$ Society Review 7, no. 4: 719-46.

Ng, Kwai Hang, and Xin He. 2017. Embedded Courts: Judicial Decision-Making in China. Cambridge, UK: Cambridge University Press.

Nordland, Rod, and Fahim Abed. 2019. "The Money Changer of Kabul: His Daughter and Her Kidnappers." New York Times, May 12. https://www.nytimes.com/2019/05/12/world/asia/ afghanistan-kidnapping-ransom.html.

North, Douglass C. 1990. Institutions, Institutional Change and Economic Performance. Cambridge, UK: Cambridge University Press.

Ostrom, Elinor. 1990. Governing the Commons: The Evolution of Institutions for Collective Action. Cambridge, UK: Cambridge University Press.

Paquin, Julie. 2012. Legal Reform and Business Contracts in Developing Economies: Trust, Culture, and Law in Dakar. London: Routledge.

Parsons, Talcott. 1937. The Structure of Social Action: A Study in Social Theory with Special Reference to a Group of Recent European Writers. New York: McGraw-Hill.

Putnam, R. D. 1993. Making Democrary Work: Civic Traditions in Modern Italy. Princeton, NJ: Princeton University Press.

Rahbari, Siavash. 2018. "From Normative Pluralism to a Unified Legal System in Afghanistan?" Asian Journal of Law and Society 5: 289-314.

Rahimi, Haroun. 2019. "To Sue or Not to Sue: How Afghan Merchants Strategically Choose to Use or Avoid Courts." Asian Journal of Comparative Law 14, no. 2: 211-44.

. 2021. "How to Create Better Hawala Regulations: A Case Study of Hawala Regulations in Afghanistan." Crime, Law and Social Change 76, no. 2: 131-48. https://doi.org/10.1007/ s10611-021-09959-w.

Ranasinghe, Prashan. 2014. "The Humdrum of Legality and the Ordering of an Ethic of Care." Law $\mathbb{E}$ Society Review 48, no. 4: 709-39.

Richman, Barak. 2004. "Firms, Courts, and Reputation Mechanisms: Towards a Positive Theory of Private Ordering." Columbia Law Review 104: 2328-67.

—. 2006. "How Community Institutions Create Economic Advantage: Jewish Diamond Merchants in New York." Law E⿱ Social Inquiry 31, no. 2: 383-420.

—. 2017. Stateless Commerce: The Diamond Network and the Persistence of Relational Exchange. Cambridge, MA: Harvard University Press.

Rosenberg, Matthew. 2011. "U.S. Treasury Blacklists Afghan Money Courier." Wall Street Journal, February 2.

Rubin, B. R. 2002. The Fragmentation of Afghanistan: State Formation and Collapse in the International System. New Haven, CT: Yale University Press.

Sagy, Tehila. 2011. "What's So Private About Private Ordering?" Law $\mathcal{E}$ Society Review 45, no. 4: 923-54.

Spector, Regina A. 2017. Order at the Bazaar: Power and Trade in Central Asia. Ithaca, NY: Cornell University Press. 
Stringham, Edward Peter. 2015. Private Governance: Creating Order in Economic and Social Life. Oxford: Oxford University Press.

Suchman, Mark C. 1995. "Managing Legitimacy: Strategic and Institutional Approaches." Academy of Management Review 20, no. 3: 571-610.

Suhrke, Astri. 2012. When More Is Less: The International Project in Afghanistan. New York: Columbia University Press.

Swenson, Geoffrey. 2017. "Why U.S. Efforts to Promote the Rule of Law in Afghanistan Failed." International Security 42, no. 1: 114-51.

. 2018. "Legal Pluralism in Theory and Practice." International Studies Review 20, no. 3: 438-62.

Tamanaha, Brian Z. 2008. "Understanding Legal Pluralism: Past to Present, Local to Global." Sydney Law Review 30: 375-411.

Thompson, Edwina. 2011. Trust Is the Coin of the Realm: Lessons from the Money Men of Afghanistan. Oxford: Oxford University Press.

Tyler, Tom. 2006. Why People Obey the Law. Princeton, NJ: Princeton University Press.

Von Benda-Beckmann, Keebat. 1981. "Forum Shopping and Shopping Forums: Dispute Processing in a Minangkabau Village in West Sumatra." Journal of Legal Pluralism 19: 117-59.

Von Benda-Beckmann, Franz, and Keebet von Benda-Beckmann. 2006. "The Dynamics of Change and Continuity in Plural Legal Orders." Journal of Legal Pluralism and Unofficial Law 38: 1-44.

Wardak, Ali. 2011. "State and Non-State Justice Systems in Afghanistan: The Need for Synergy." University of Pennsylvania Journal of International Law 32, no. 5: 1305-24.

Wardak, Ali, and John Braithwaite. 2013. "Crime and War in Afghanistan: Part II: A Jeffersonian Alternative?" British Journal of Criminology 53, no. 2: 197-214.

West, Mark D. 1997. "Legal Rules and Social Norms in Japan's Secret World of Sumo." Journal of Legal Studies 26, no. 1: 165-201.

Woodman, Gordon. 1998. "Ideological Combat and Social Observation: Recent Debate About Legal Pluralism." Journal of Legal Pluralism 42: 21-59.

Woodruff, Christopher. 1998. "Contract Enforcement and Trade Liberalization in Mexico's Footwear Industry." World Development 26, no. 6: 979-91. 